\title{
How ecosystem services and agroecology are greening French agriculture through its reterritorialization
}

\author{
$\underline{\text { Xavier Arnauld de Sartre }}^{1}$, Marion Charbonneau $^{2}$ and Orianne Charrier $^{2}$
}

\begin{abstract}
Even if agroecology and ecosystem services are multidimensional framework concepts, recognizing the technical, social, and ecological dimensions of agriculture, they have developed from different traditions (conservation biology for ecosystem services, agronomy for agroecology). We compare in a specific French region how these frameworks are interpreted through two different instruments of French agricultural policy inspired by ecosystem services (the agroenvironmental measures of the common agricultural policy) and by agroecology principles (the economic and environmental interest groups of the French national policy for agroecology). After having analyzed the theoretical and political foundations of these instruments, we focused on their spatial and political consequences. We conclude that the contrast between the agroecology and ecosystem services approaches tends to fade when we analyze how each of these instruments is put in place. Even if the two instruments obey a different logic (compensate for failure to protect sensitive areas for ecosystem services, trigger a shift in the dynamics of agriculture for agroecology), even if they are driven, funded, and involving different players, even if they locally occupy different places, the changes to agriculture brought by the two instruments tend to converge toward the same result. They try to limit the impacts of agriculture, are part of the greener farming movement, and they are driving a process of opening up agriculture to other sectors. They also aim at increasing farmers' income by offsetting the failures of an insufficiently remunerative market and capturing some of the production margins. By the end, these instruments are designed to help conventional systems move toward greater integration in the socio-political territories in which they operate, toward greater autonomy and less dependence on phytosanitary products.
\end{abstract}

Key Words: agriculture; agroecology; common agricultural policy; ecosystem services; France; local authority

\section{INTRODUCTION}

The special feature in which this paper is published focuses on understanding how the ecosystem services approach can help to establish agroecology on an operational basis. Our argument draws on the similarity of the two concepts: agroecology and ecosystem services are both multidimensional, in that they recognize the technical, social, and ecological dimensions of agriculture. However, although the characteristics of these two concepts have strong similarities, they have developed from different traditions: the idea of ecosystem services comes from conservation biology whereas agroecology is a concept developed by agronomists aiming to bring ecology into agronomy and by social movements opposed to agricultural modernization. Although the two traditions have common objectives and rationales, they differ significantly in the way they consider social players, transition pathways, etc. In this paper, we argue that even if each concept has its specificity, they both participate in a policy aiming for a greener agriculture by allowing the French agricultural sector to integrate local and environmental issues.

Since the Second World War, French agricultural policy and the EU's common agricultural policy (CAP) have organized agricultural production as a specific economic and political sector, with its own rules, and oriented toward high productivity. This agricultural policy was conceived as embedded in global markets and was carved out of its local context. This policy gradually changed since the mid-1980s because of the French movement of decentralization, the health and economic crisis of agriculture, and the environmental stakes (Muller 1990). However, although most of these transformations were brought from outside the agricultural sector, over the last 10 years we have observed a transformation coming from the agricultural sector itself, using agroecology and ecosystem service as public policy categories.
Agricultural policies in Europe, and especially in France, are applying both public policy categories at once. Having greatly modernized European agriculture after the Second World War, the EU, which has wide-ranging legal authority in agriculture, transformed its agricultural policy during the 1990s to give greater weight to environmental and social considerations. The "second pillar" of the common agricultural policy, which complements the system of direct payments to farmers (the so-called "first pillar"), can be considered as inspired by principles from the ecosystem services concept (Tancoigne et al. 2014). At the same time, the French government, which also has authority in agriculture, launched an "agroecology project for France" in 2012 (projet agro-écologique pour la France) with its own instruments - which differ from those of the European Union.

By comparing the two policies in a specific French region (the Nouvelle Aquitaine, in southwest France), we aim to understand how the two concepts are interpreted through the instruments of French agricultural policy and how both participate in defining a policy aimed at improving agriculture embeddedness in local contexts and the integration of environmental issues in the agricultural sector concerns (Brénac 1988) of. We will focus, in particular, on the spatial and political consequences of these interpretations, showing that instruments inspired by the ecosystem services concept are not applied in the same areas as agroecological instruments. Although the instruments are very different, they also share some characteristics that help to understand to what extent French agriculture is changing with the application of policies that combine the two concepts. French agriculture appears here as a case that illustrates, in a real situation, different pathways toward greener farming systems through desectorization and greater autonomy for farmers, pathways that are paved with difficulties but also relatively 
coherent. They show how the French agricultural sector favors a reconciliation of agriculture with its local contexts and with environmental issues.

\section{ECOSYSTEM SERVICES AND AGROECOLOGY: TWO DIFFERENT FRAMEWORKS FOR GREENER AGRICULTURE}

\section{Contrasting positions on ecological modernization and the greening of agriculture}

Although highly contested and, to some, progressing too slowly, modernity has begun a metamorphosis that stems in particular from an awareness of the enormous risks we run by cutting modernity loose from its ecological foundations (Beck et al. 1994, Gunderson and Holling 2002, Beck 2016). The debate today is not about whether or not ecological processes are being taken into account in the different dimensions of modernity, but about how this should be done. In the past, two main pathways toward modernization have been contrasted in both scientific literature and societal debates, the one emphasizing the social-ecological dimensions of relationships with the environment and advocating locally based solutions, and the other counting on technological and global political solutions. This contrast is evident in scientific literature, for instance when the ecological modernization movement argues that "solutions [to environmental problems] necessarily lie in more modernization and super-industrialization" (Buttel 2000:60), while political ecologists, for instance, argue that "we need a set of interventions and frameworks capable of laying the groundwork upon which we in the North, and the South too in different ways, must change our whole way of life" (Peet et al. 2010:41).

These opposing views underlie, in many ways, the structure of overall assessments such as the scenarios defined in the Millennium Ecosystem Assessment, especially the contrast between the TechnoGarden scenario that relies heavily on "environmentally sound technology [and] highly managed, often engineered, ecosystems" and the adaptive Mosaic scenario that aims to strengthen "local institutions and local ecosystem management” (Millennium Ecosystem Assessment 2005:73).

This is particularly the case in debates on the greening of agriculture. These are structured around the role of technology, especially pesticides, fertilizers, and genetically modified plants (GMO), and links with global markets (Levidow et al. 2013, Ollivier and Bellon 2013). Some hold that so-called "precision agriculture" or "conservation agriculture" can, thanks to new technologies such as no-till, in combination with GMOs, preserve soils, increase yields, and help to preserve areas with high biodiversity, according to the debate on Indirect Land Use Change (Green et al. 2005). To others, innovation should come from farmers, who have better knowledge on how to manage the ecosystems in which they have sometimes lived for generations; local markets are preferred to global markets, and technology should only come into the equation if it solves problems that farmers are faced with (Altieri 1995) - a position that these authors present as opposed to ecological modernization (Rosset and Altieri 1997).

Obviously, many attempts have been made to resolve these opposing viewpoints. Lowe et al. (2002) studied the transformation of the CAP, showing that between two opposed visions of agriculture "a 'third way' has emerged, centred upon what is claimed to be a particular and unique European model of agriculture whose defining feature is held to be its 'multifunctionality'. The concept implies that agriculture produces benefits and services other than food commodities" (Lowe et al. 2002:1). Multifunctionality, replaced by ecosystem services (Bonnal et al. 2012), can be analyzed as a "woolly public policy category" (Dubois 1998:169). Its vagueness is intentional. Indeed, the French government, as the European Union, aims at transforming agriculture but lacks the legitimacy to do so because the agricultural sector perceives itself as independent and perceives environmental issues as illegitimate interference in their market-based logics. As Dubois showed in the case of French cultural policy, the use of a woolly concepts as public policy categories allows the enlisting of many actors. These categories are soon transformed into instruments whose objectives are also vague and that, as with all instruments, make sense when being applied and appropriated by the different stakeholders.

Ecosystem services appear as one of these woolly public policy categories: in the two texts published in 1997, ecosystem services are presented both as a concept that could make it possible to "capture nature in commercial markets," thereby giving nature more "weight in policy decisions" (Costanza et al. 1997:253), and to help local managers make appropriate decisions in local situations (Daily 1997). As a public policy category, ecosystem services (ES) can both help to internalize market externalities and support local action. Many references and debates around this idea emphasize both of these ES dimensions, thus making ES a fundamental tool for the greening of modernity. Indeed, as Kull et al. (2015) show, it is at the same time a woolly category based on a metaphor that does not allow to clearly identify its objectives and a public policy instrument whose uses strongly depend on the objectives of the stakeholders that appropriate it. Agroecology is set to play the same role. At the global scale, the United Nations Food and Agriculture Organization (FAO) recently argued in favor of agroecology as a model for the future of agriculture (Loconto 2017). Some countries have followed the same path. The French Ministry for Agriculture, for instance, adopted a law on "the future of agriculture" in 2014 that makes agroecology the central model for France's future, and greener, agriculture. As ecosystem services, agroecology is quite woolly because it comes from different traditions (Wezel and Soldat 2009). But although ecosystem services and agroecology are both public policy categories aiming for greener agriculture, they did not develop from the same intellectual traditions and their goals are not comparable.

\section{Agroecology and ecosystem services, two different traditions for two different pathways toward greener agriculture}

The vagueness of ecosystem services and agroecology is critical to allow them to participate from inside the agricultural sector to a greening of agriculture in a context of a strong lack of legitimacy for such an issue among many farmers. The concept of ecosystem services originates in the link between conservation biology and ecological economics (Gómez-Baggethun et al. 2010, Kull et al. 2015). The concept has been much debated, with many authors focusing on its operational applications (Biggs et al. 2012, Jacobs et al. 2014, Bennett et al. 2015) while others are highly critical. Because the idea of ecosystem services is directly linked to markets, aiming to turn the environment into a set of metrics to 
assess the economic value of nature, it can be seen "as at least in the vanguard of the neoliberalization of nature, if not as its flagship" (Dempsey and Robertson 2012). Many publications criticize this use of the ecosystem services concept (for example Clausen and Longo 2012, Maris 2014, Silvertown 2015). But many authors also point out that the use of ES deviates from neoliberal doctrine (Dempsey and Robertson 2012, McAfee 2012, Kull et al. 2015) and, even as they recognize the neoliberal potential of the ES concept, they show that it can also be used for many other purposes, for example, to aid in decision making (Laurans et al. 2013) or to support learning or consultations (Barnaud and Antona 2014), and that even when it is applied to markets, it takes on many forms (Gómez-Baggethun and Muradian 2015). Green capitalism (Dempsey and Robertson 2012) or ecological modernization (Mol et al. 2009) encompass players who are too diverse and wide-ranging to allow the use of a single bridge concept such as ecosystem services. It appears as an appropriate tool to work toward ecological modernization in agriculture, where it is consistent with both the techno-garden and the adaptive mosaic scenarios of the agri-environmental measures.

According to Wezel and Soldat (2009), agroecology was first proposed by agronomists who used the term to describe the use of ecological methods in agriculture (Bensin 1928, Klages 1942, Tischler 1965). During the 1970s, agroecology emerged both as a science that studies agro-ecosystems through its own methodology and conceptual framework, in continuity with the earlier tradition of agroecology, and as a critical approach to the modernization of agriculture. Because the second agricultural revolution rests on artificializing nature and overmechanization, agroecology, by recognizing ecological processes and ecological knowledge, appeared as a countermodel for agriculture modernization and became integral to various social movements seeking alternatives to industrial agri-food systems (Cox and Atkins 1979, Altieri 1987). Agroecology thus increasingly became part of the agenda of social movements advocating the transformation of agri-food systems at every scale (Altieri 1987, Francis et al. 2003, Caporali 2011, Gliessman 2014).

Agroecology today is at once a transdisciplinary science, a set of practices for greener agriculture, and a social movement (Wezel et al. 2009). Different agroecology paradigms coexist, even if each author emphasizes one dimension of agroecology over others (Goulet et al. 2012). Relationships with markets, technology, etc., are much discussed among agroecologists, with "true agroecology" frequently opposed to other forms (Levidow et al. 2014). All these forms of agroecology are now converging with the recent recognition by agroecologists of the importance of the local dimensions of food systems. These have become a mark of green, locally produced, high-quality agricultural produce, so that agroecology has become a production system suited to the adaptive mosaic in agri-environmental measures scenarios.

Although both public policy categories acknowledge the greening of agriculture, ecosystem services and agroecology refer to models of modernization that are potentially opposed to each other, one being linked to alternative production systems and the other used either as a scientific basis for the bioeconomy or as a basis for agroecological approaches (Levidow et al. 2013). These differences stand out clearly when both public action categories become policy instruments (Lascoumes and Le Gales 2004) for greener agriculture. In this case, we see that if the two tools rest on different cognitive foundations, both share a greater embeddedness in local contexts, i.e., a "transformation of public action, marked by an increased localization and a greater transversality in the handling of public problems" (Douillet et al. 2015:336). We aim in this paper to study how these instruments function when they are being applied, how each one organizes the relationships between public power and its recipients: how do social actors use these tools?

\section{Agroecology and ecosystem services in Europe}

In Europe, and particularly in France, agroecology and ecosystem services have been directly or indirectly inspiring public policies, including the redefinition of the common agricultural policy (CAP), since the 1990s. In response to the criticisms and externalities of the productivist principles strongly supported by the CAP, the European Union defined a mechanism to provide monetary compensation to farmers applying environmentally friendly practices, referred to as payment for ecosystem services (Valette et al. 2012, Tancoigne et al. 2014). The debates that led to a transformation of the CAP took place in 1990, when the ecosystem services concept had not reached the success it has since 2000. Multifunctionnality was then the concept used to assert that agriculture produces more than food commodities (Lowe et al. 2002). When ecosystem services gained its legitimacy, an alliance between economists and conservation biologists substituted multifunctionality with ecosystem services (Bonnal et al. 2012, Ansaloni and Tournay 2013). The mechanism, deployed as "agrienvironmental measures" (AEM), was to represent at least $25 \%$ of the total amount of money allocated by each country, under the second pillar of the CAP, to rural development.

Perraud (1998), Lowe at al. (2002), Ansaloni and Tournay (2013), Dupraz and Pech (2009, unpublished manuscript), and Chatellier and Guyomard (2011) have shown how the Member States and their regions interpreted agri-environmental programs by virtue of the subsidiarity principle. Germany, the Netherlands, and northern Italy (Perraud 1998), for example, have chosen to use these measures for the "promotion of innovative production methods such as integrated production and organic farming" (Deverre and De Sainte Marie 2008:86), while Finland, Sweden, and Austria have "used agri-environmental payments to compensate for the decline in their agricultural prices, following their entry into the EU in 1995" (Dupraz and Pech 2009, unpublished manuscript). The UK has used them for conservation objectives, including birds and natural habitats (Ansaloni and Tournay 2013). France, for its part, is preoccupied with problems of rural desertification and regional imbalances (Facchini 1999) and is seeking to compensate for the "income differences between cattle farmers and grain producers" (Ansaloni and Tournay 2013:51). France thus chose to use agroecology as an instrument for the preservation of "rare and sensitive biotopes," and especially for spatial planning by offering specific support for fragile environments and areas undergoing rural desertification or particularly exposed to natural hazards. The first AEM (1980s, 1992) were thus essentially used "by natural area managers or local authorities for a purpose of conservation or restoration of environments [...] and have mainly concerned a marginal category of farmers: pastoral herders" (Deverre and De Sainte Marie 2008:92), struggling to settle in "high priority areas for the environment" (Dupraz and Pech 2009, unpublished manuscript). 
In 2012, realizing that the main farming systems in France were not concerned by the European agri-environmental policy, the new French Ministry of Agriculture (DRAAF 2016) launched its agroecology project under an Act "for the future of agriculture." Two of the specific instruments provided for by this Act are of interest here. The first is in continuity with pre-existing instruments and transforms some AEM to create "systemic AEM" (aimed at transforming farming systems) and "territorial AEM." The latter can only be considered as part of a project for a local area (based on a diagnosis of the socio-environmental situation, with specific goals, etc.) to meet objectives that are both economic and environmental, coconstructed by different kinds of players and used in synergy with other instruments to promote more ecologically compatible farming systems. This legal instrument thus aims to turn AEMs into agroecological tools.

Another legal instrument, the GIEE (for groupements d'intérêt écologique et économique, or economic and environmental interest groups) was devised for the major agricultural systems. GIEEs are groups of farmers who define a project to switch to more sustainable farming practices (referred to in terms of "social, environmental and economic performance") or to consolidate changes already under way. These groups are awarded a label that backs up their applications for funding from different sources (European or French public funds). These instruments are designed as agroecological because they are based on local farmers' networks and on social, economic, and ecological changes to farming practices. This definition of agroecology has been highly contested by social movements that have been campaigning in favor of agroecology for many years. They argue that the "institutional definition of agroecology" undermines its systemic character and its ambition to achieve deep social change.

This kind of opposition should remind us that agroecology has its roots in radical social movements that predate its institutionalization by the French Ministry of Agriculture. The ecosystem services category, when used in AEMs, has been similarly institutionalized but it is rooted in a different tradition, which stems from an alliance between conservation biology and ecological economics. The latter is embedded in the ecological modernization movement, whereas the former is sympathetic to critical socio-environmental movements, but both are being reinterpreted by French agricultural institutions. Do these origins structure the way these instruments are applied? We assume that the different origins of these instruments explain the differences observed when they are applied, especially in terms of the areas in which they are available and the players who promote them. However, we will see that these distinctions become blurred when viewed through the collaborative networks that are being established locally.

\section{METHODOLOGY}

To analyze the differences between these two instruments, we studied their application in the Nouvelle Aquitaine Region. The reason for this choice lies in two different dynamics that arise from the process of territorialization that has characterized French public policies since the 1980s (Jobert and Muller 1987, Douillet 2003, Moquay 2008).

The first is related to decentralization and the increasing importance of the regions in the sphere of agricultural policies. In view of the subsidiarity principle of EU policies and the French state's strong commitment to a "redistribution of power to local and regional elected officials, civil society players (often acting through ecological associations and / or advocacy groups for public service users) and business organizations (delegates, chambers of commerce, farmers, etc.)" (Caillaud 2015:322), agricultural policies are increasingly tailored to the regional scale. The two instruments studied here are no exception. In this context, the Nouvelle Aquitaine case appears to be of particular interest to understand the increasing importance of regionally driven factors. This administrative region was created in 2014 by merging the three former regions of Poitou-Charentes, Limousin, and Aquitaine. It runs three rural development programs as well as supporting a number of agri-environmental climate schemes $(\mathrm{AECS})^{[1]}$ and GIEEs selected until 2016 under three separate calls for projects ${ }^{[2]}$.

The second, which seeks to involve nonagricultural players and to encourage participatory and procedural modes of action (Lascoumes and Le Bourhis 1998), forms a basis for multiplayer policies and allows these players a certain amount of flexibility in the way they implement their projects. This is fully reflected in the AECS and GIEEs, which are characterized by a wide range of proposals that vary from one area to another depending on the players involved, on the scales and perimeters of the target areas, and on local issues and configurations. Given the key importance of the local context (Torre 2009) in the emergence and subsequent implementation of certain local initiatives (Allaire et al. 2014, Allaire 2016), our analysis of the Nouvelle Aquitaine region allows comparisons between existing projects. The Nouvelle Aquitaine region is the leading French and European region in terms of agricultural turnover, total cultivated area, and forest cover. Farming is diversified, with two winegrowing basins around Bordeaux and Cognac, cereal crops in the valleys to the south, market gardening, horticultural and fruit production in the Garonne valley in particular, timber and poultry production in the Landes, and dairy, cattle, and sheep farming in the Pyrenees and Limousin. With its numerous AECS, because of in particular the presence of wetlands and important livestock farming areas, the GIEE system here is of particular interest because it currently encompasses 83 of the 411 groups identified in France in early 2017.

In Nouvelle Aquitaine, we conducted a comprehensive analysis of the location of 94 AECS and 83 GIEE projects in the region, their content, and the players involved. This drew in particular on two studies completed in 2017 by two Master's students (Berti 2017, Figadère 2017). Based on a study of the AECS and GIEE projects that received labels between 2015 and 2017 and supplemented by interviews with the main players, we sought to understand how these two instruments coexist in the field by looking at the spaces they occupy, the players who support or actively deploy them, and the operational themes around which they converge.

We first mapped all the projects. The fact that each AECS is zoned made it easy to identify their contours (Fig. 1). On the other hand, it was impossible to map the GIEE, which do not have particular spatial boundaries. We therefore chose to represent each GIEE in the form of cluster points proportional to the number of farmers involved. When the municipalities in which they were based were known, the clusters were centered on the municipalities; when the 
information was more approximate, a broader area of attachment was outlined $^{[3]}$. The aim was to locate the overall area of their deployment. This was a matter of highlighting AECS and GIEE "homes" and "deserts," but also of identifying areas of overlap that would show coexistence, or even synergies, between the instruments.

Fig. 1. Mirror mapping. This map does not represent systemic agri-environmental climate schemes (AECS that engage the whole farms, and not only some parcels). Indeed, these AECS are at a "departement" scale in order to compensate former common agricultural policy (CAP) incentives such as PHAE (agro-environmental grassland incentives), as allowed by the last CAP programming. Representing them in this map would hide the differences between the areas of application of the two instruments, while systemic agri-environmental measures are not instruments inspired by the ecosystem services notion.

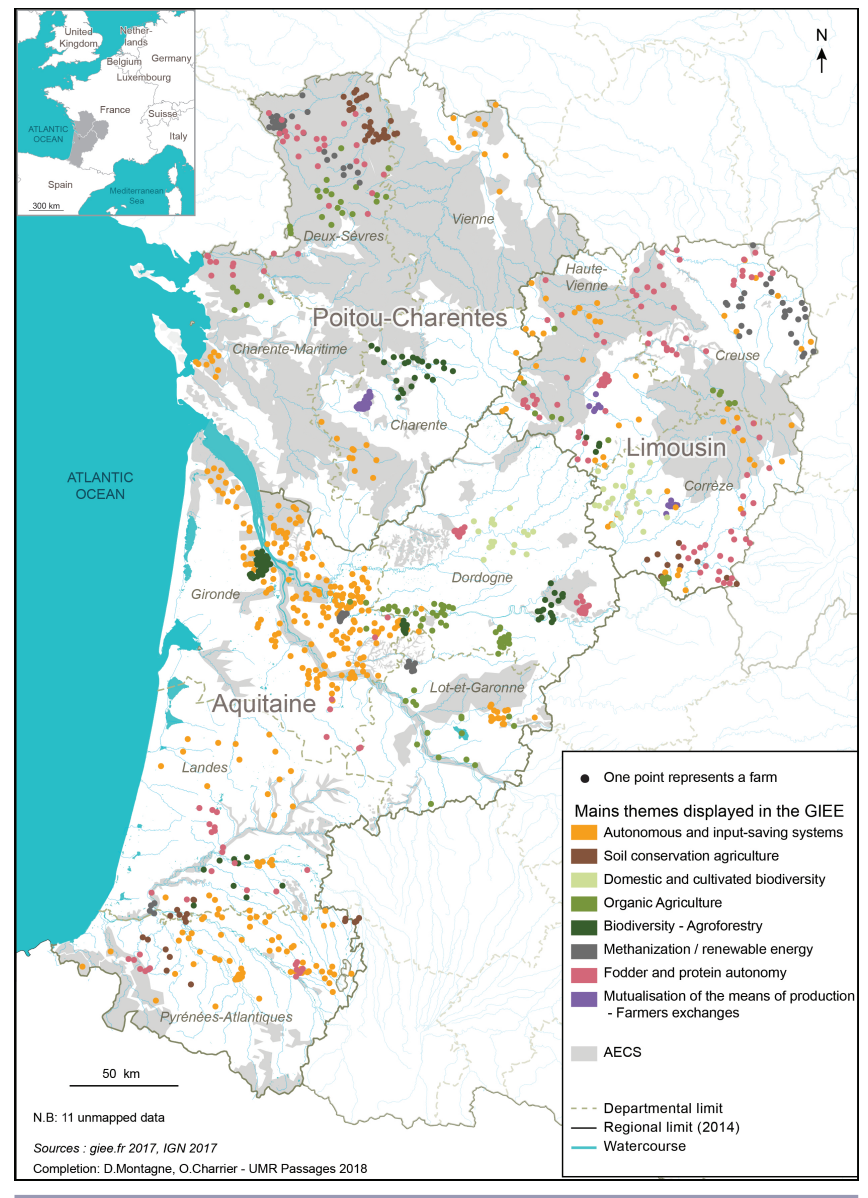

The sociograms (Moreno 1960), constructed with GEPHI software during the second phase of the analysis, enabled us to identify the local players involved in these projects (farmers, paraagricultural organizations, local authorities, associations, businesses, etc.) and the collaborative networks that emerged from them. Three types of networks were built up. The first includes all the players involved in the 83 GIEE in Nouvelle Aquitaine, the second is made up of all the "operators" and lead or outreach organizations of the 94 AECS in Nouvelle Aquitaine, and the third combines the two in order to identify convergences or divisions between different ways of working. The sociograms created as part of the research reported here are not intended as a means of analyzing the positions of players in the networks (Bonacich 1987, Lazega 1994) or the density of links (Granovetter 1973), but rather to provide a basis for highlighting those players who adhere to these mechanisms and belong to the clusters that emerged. Are the networks polarized, sectored, fragmented? Which players work together, and around which projects?

Finally, by analyzing the content of the projects we were able to pinpoint the objectives sought and the themes worked on. For the GIEE, manual analysis of all projects involving the two instruments were supplemented by a semiautomatic analysis using Shinx-IQ. The results of this study will be published separately but some considerations are highlighted here.

\section{RESULTS}

\section{Two instruments built on different foundations}

Although applied on the same scale and aiming to establish greener practices, the foundations of these two instruments differ. AECMs are set up for selected AECS during calls for projects launched by the regions. AECS are necessarily introduced in environmentally sensitive target zones that are given priority in regional rural development programs. They are supported by agencies with "environmental or agronomic authority" and defined in collaboration with the regions, devolved state agencies, and stakeholders in the relevant areas. They are based on a diagnosis of the area that must identify the main local issues, particularly in terms of biodiversity conservation and preserving water quality, and define a target zone for action. They detail which AECMs can be applied for by adapting certain specifications to local issues. Any farmer owning a parcel in an AECS zone can then apply, on a voluntary basis, for one or more AECM. In return, they receive compensation to offset the additional cost of implementing the contract.

GIEEs, on the other hand, are groups formed by farmers around a common project. These projects aim to help farmers switch to systems that improve their economic, environmental, and social performance. The groups are given the GIEE label by a committee responsible for evaluating and selecting the projects according to 10 evaluation criteria ${ }^{[4]}$. Apart from the first four criteria, which concern the goals of agroecology policy (each of which must also be approved, otherwise the application is rejected), the other six criteria are specific to the GIEE instrument. Nevertheless, only the criterion relating to the collective dimension of the project is required in all cases, because functioning as a group is considered to be the driving force of change. Once labelled, the GIEE are often accompanied by a para-agricultural agency to help them implement their project and build on their experience. The GIEE label does not attract specific funding but facilitates access to public funds.

The logic behind these two instruments is different. GIEEs seek to stimulate a shift in operational farm practices, while AECS aim to protect a particular area. These differences in objectives explain why the meaning of "territory" in the two instruments is very different. In both cases, the procedures are considered a priori to be "territorial" in nature, either because the proposal is coconstructed by local players (AECS), or because they emerged 
at the grass-roots level among the farmers themselves (GIEE). They imply the involvement of multiple players and are driven by a project leader who knows the area well and is therefore in a position to adapt projects to local farming conditions. But in the case of AECS, adaptation of the system to the territory is based on a topographic metric: the territory is circumscribed on the basis of technical criteria for environmental aspects and the area targeted for action is continuous and strictly defined. The GIEEs are based on a collective of farmers from the same area, which is described as the "territory" but never clearly circumscribed. They work on a networking principle based on topological metrics.

From these distinct conceptions of "the territory" arises the fact that the instruments do not give farmers the same role, even though both are based on a "procedural" mode of action (Lascoumes and Le Bourhis 1998) and operate on a voluntary basis. In the case of AECS, farmers are consulted to set up projects, but they are above all the targets of top down measures that guide their practices on the basis of due care. In GIEEs, the farmers define their goals themselves: undeterred by specifications, they choose whichever path they want to achieve these. Recognition of farmers' know-how and knowledge is therefore the basis of the instrument, AECMs, which regulate the practices that farmers are required to implement. In a GIEE, farmers are invited to think about the scale of the cropping system, the production system, and even localized food systems. AECMs, on the other hand, are still attached to the parcel (the "system" that AECMs have still allowed to drive changes on the scale of each farm since the last programming period).

The two instruments therefore differ in their objectives, in their conception of the "territory," in the way farmers are considered and in the preferred scales of action. Logically, these differences in the very basis of the two instruments are also apparent in their implementation.

\section{Players from two different spheres who act in separate spaces}

Agroecology outside protected areas: toward spatial partitioning? Our study of the spatial deployment of the two instruments shows that each occupies distinct spaces. Effects of concentration are observed at different scales ${ }^{[5]}$, with some spaces seeming to have favored one of the two instruments.

At the regional level, the former Aquitaine and Limousin regions have a large number of GIEEs while the former Poitou-Charentes region has many AECS. This pattern is found both in the areas covered by the AECS (Fig. 1) and in the networks of players (Fig. 2). The sociogram around the two instruments clearly shows three regionalized subgroups. These are connected to each other by agencies that act as brokers, but few of the links are active (Granovetter 1973) and a noticeably large number of players are involved in agroecology in the Limousin and in AECS in the Poitou-Charentes. The AEMs introduced since the 1990s in the Charente wetlands to maintain cattle farming and water quality (Harreau 2009) account for the importance of this instrument in the north of the Nouvelle Aquitaine region.

This concentration effect can be found at the département level (Fig. 1). Although some départements, such as the Haute-Vienne, apply both instruments, others seem to have favored one over the other. AECS are very numerous and cover a large area of the Vienne and Charente-Maritime départements, but GIEEs are more numerous in the Creuse, Dordogne, and Landes. This can be explained by the significant involvement in this instrument of certain sectors or players in each département.

The study of more exact locations of the different projects confirms this spatial partitioning. The localization of both instruments in Figure 1 shows that most GIEEs are located outside AECS areas. Less than $20 \%$ of GIEEs are located in areas where preserving water quality or a particular environment (wetlands in particular) is a particular issue, and only $6.7 \%$ of the players, mainly Chambers of Agriculture, are involved in both GIEEs and AECS (Fig. 2). Areas facing a particular social or environmental issue are covered by targeted measures to compensate farmers for the financial cost of implementing environmentally friendly agricultural practices. Collective projects with the GIEE label essentially emerged outside these areas. In 2013, almost half of the "CASDAR" projects, which prefigured the GIEE, were located in a AECS area, particularly in drinking water catchments (this is more particularly the case in Poitou-Charentes where five of the six CASDAR projects selected at the time were registered either in a Natura 2000 zone or in a water catchment zone $\left.\left[\mathrm{AAC}^{[6]}\right]\right)$. A distinctive outcome of the mechanism introduced by the Agricultural Modernization Act therefore seems to be the spread of agroecology outside sensitive areas, especially in the Gironde, Pyrénées-Atlantiques, and Creuse départements.

In some areas, however, the GIEE and AECS seem to have concentrated in the same places (Haute-Vienne, Deux-Sèvres, PNR Millevaches), thus forming greening hubs, as opposed to the "empty zones" that appear to have almost no mechanisms of this kind (the north of the Creuse département, the east of the Charente, the north of the Dordogne, the south of the Gironde, and Lot-et-Garonne and the Aquitaine coast).

Two kinds of logic coexist. In many cases, the difference between areas with AECS and GIEEs reflect a pattern of spatial dissemination of greener agriculture. In other cases, agroecology initiatives seem to concentrate around AECS areas, whereas some areas seem to have virtually none of these schemes at all. As Allaire (2016) observed for organic farming, a phenomenon of spatiotemporal dependence may explain why some areas appear to be more favorable than others to the greening of agriculture.

Ultimately, the two instruments can therefore either become established in separate areas or overlap, thus creating either competition or synergies.

From an agri-environment dominated by public players and environmental associations to agroecology driven by the paraagricultural sphere

This kind of spatial partitioning is also reflected in the profiles of the players involved in the two instruments. Although the Chambers of Agriculture ${ }^{[7]}$ are involved in similar proportions in both instruments $(45 \%)$, other players clearly differ between the GIEEs, which are supported by specialized agricultural organizations $\left(\mathrm{CIVAM}^{[8]}\right.$, CUMA ${ }^{[9]}$, technical institutes, scientists, agricultural unions, etc.), and the AECS, which involve players whose authority extend well beyond the agricultural sphere (municipal federations, SIVUs ${ }^{[10]}$, associations, etc.). This contrast between the sectoral logic on the one hand and the territorial logic on the other is found as much in the way projects are managed as in their conduct on the ground. 
Fig. 2. The GIEE (groupements d'intérêt écologique et économique, or economic and environmental interest groups) and agrienvironmental climate schemes (AECS) network in Nouvelle Aquitaine (2017).

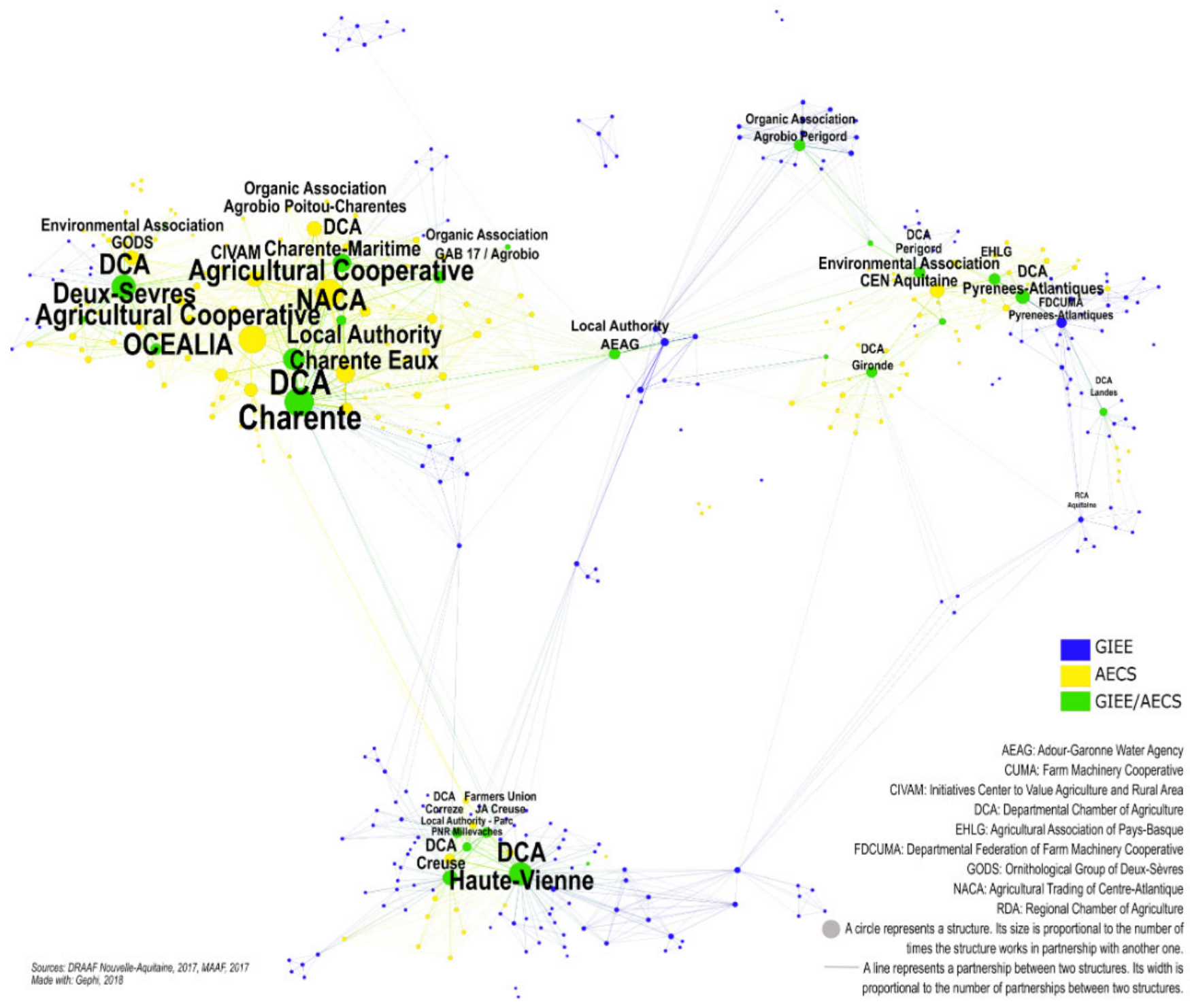

Thus, territorial communities (such as municipal federations or joint water management agencies), environmental associations $\left(\mathrm{CEN}^{[11]}, \mathrm{LPO}^{[12]}\right.$, etc.) and regional nature parks ${ }^{[13]}$, run AECS that are not coordinated by the Chambers of Agriculture (Figs. 3 and 4). These players also often contribute to their deployment on the ground through AECM implementation. The fact that farming has a direct impact on the areas for which they are responsible explains the preponderance of these territorial players in this instrument. This first and foremost reflects the fact that the AEMs have been the main financial instruments for agricultural management in Natura 2000 areas (often run by nature protection associations) and in AACs (often run by the SIVU) aiming to preserve the quality of drinking water from diffuse pollution. Our analysis of the networks of players emerging around AECS testifies to the particular role of these agencies in this instrument. In the Poitou-Charentes département for example (Fig. 5), the AECS are organized around issues that are closely linked to water. This translates into the involvement of many different players specializing in water management and linked together through regional programs to preserve drinking water quality. However, the Chambers of Agriculture are still often the technical partners (Gassiat and Zahm 2013). In the Limousin area, the entire AECS network (Fig. 5) is organized around two main players, the Chamber of Agriculture and the Conservatoire des Espaces naturels du Limousin, which have close links with the Millevaches Regional Nature Parks and with local players involved in biodiversity and water protection. Similarly, in the former Aquitaine region, the CEN for Aquitaine is a central player involved both as a partner in a large number of AECS and as an intermediary between the various players involved in these 
Fig. 3. Agencies managing the agri-environmental climate schemes in Nouvelle Aquitaine (2017).

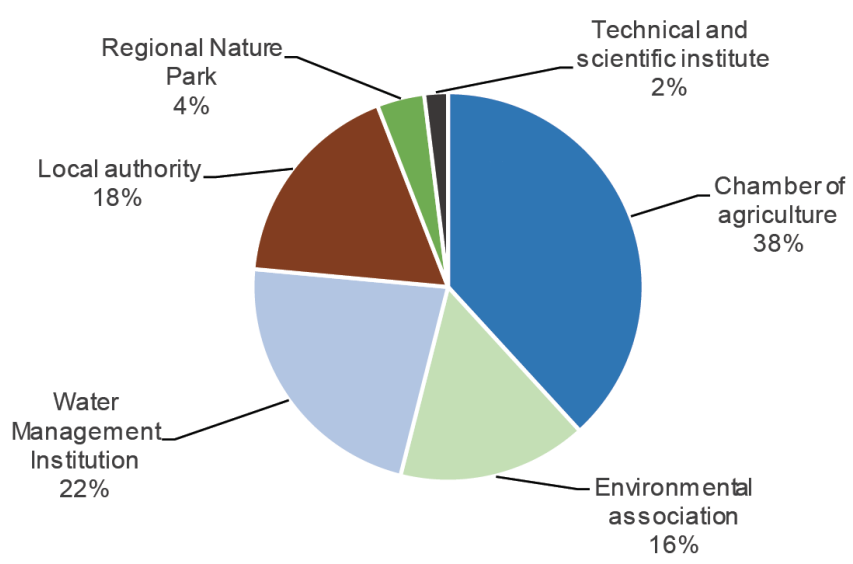

Fig. 4. Agri-environmental climate scheme outreach agencies in Nouvelle Aquitaine (2017).

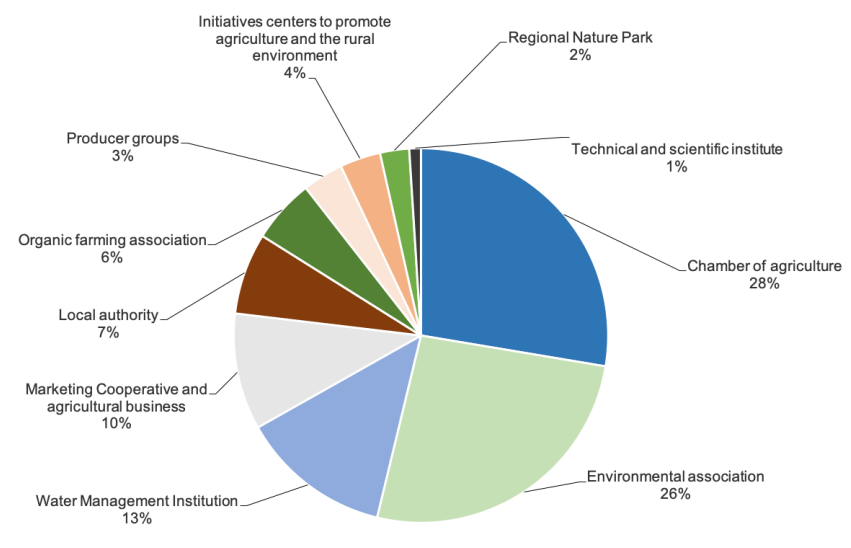

Fig. 5. The agri-environmental climate scheme network in Poitou-Charentes and Limousin (2017).

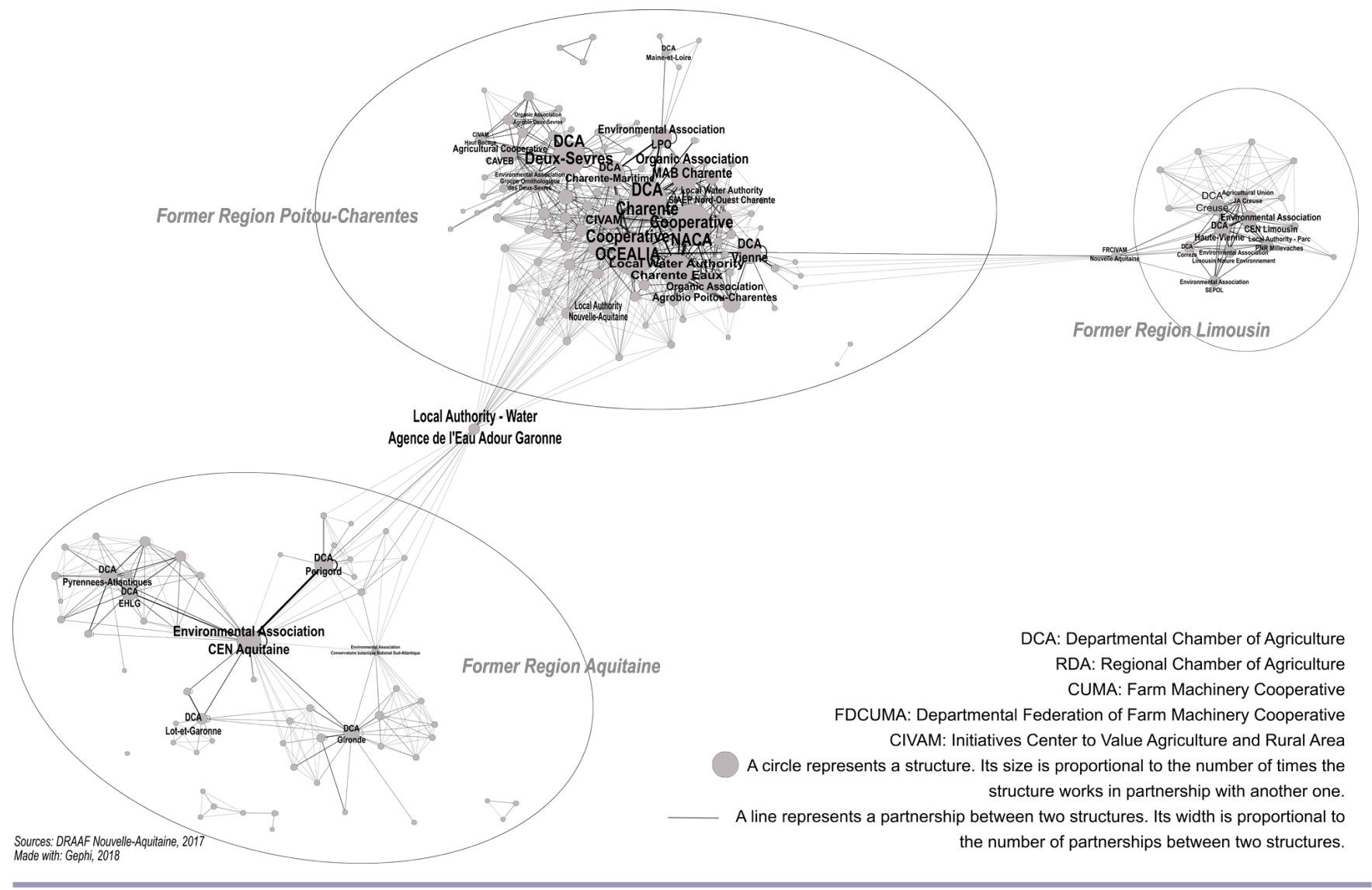

same AECS. The decline of the "traditional operators" (Chambers of Agriculture) observed by Gassiat and Zahm (2013) in areas with water issues seems to be confirmed here, and also concerns areas with biodiversity issues.
In the GIEE on the other hand, para-agricultural agencies predominate and the groups are not supported by any local authority or environmental association (Fig. 6). Our analysis of the networks of players forming around these GIEE shows that the six subgroups at the département scale (Fig. 7) are polarized 
Fig. 6. Outreach agencies for GIEEs (groupements d'intérêt écologique et économique, or economic and environmental interest groups) in Nouvelle Aquitaine (2017).

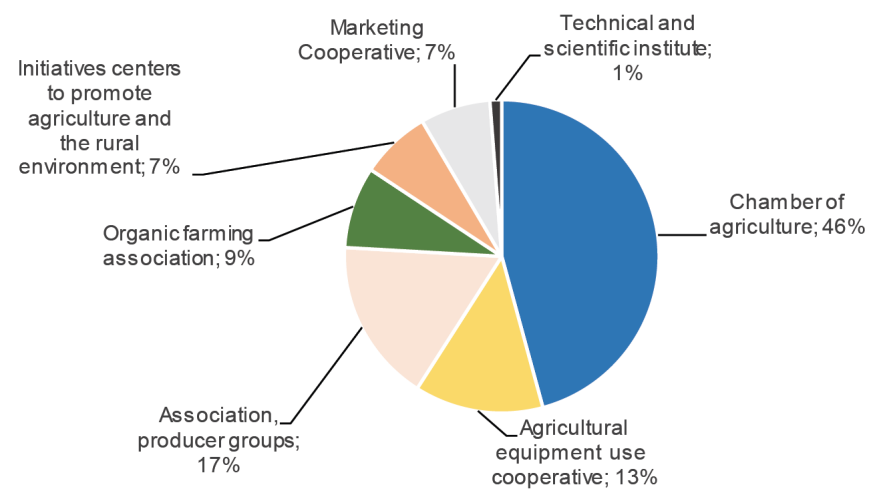

Fig. 7. The GIEEs (groupements d'intérêt écologique et économique, or economic and environmental interest groups) network in Nouvelle Aquitaine (2017). (GIEE sociogram for NA)

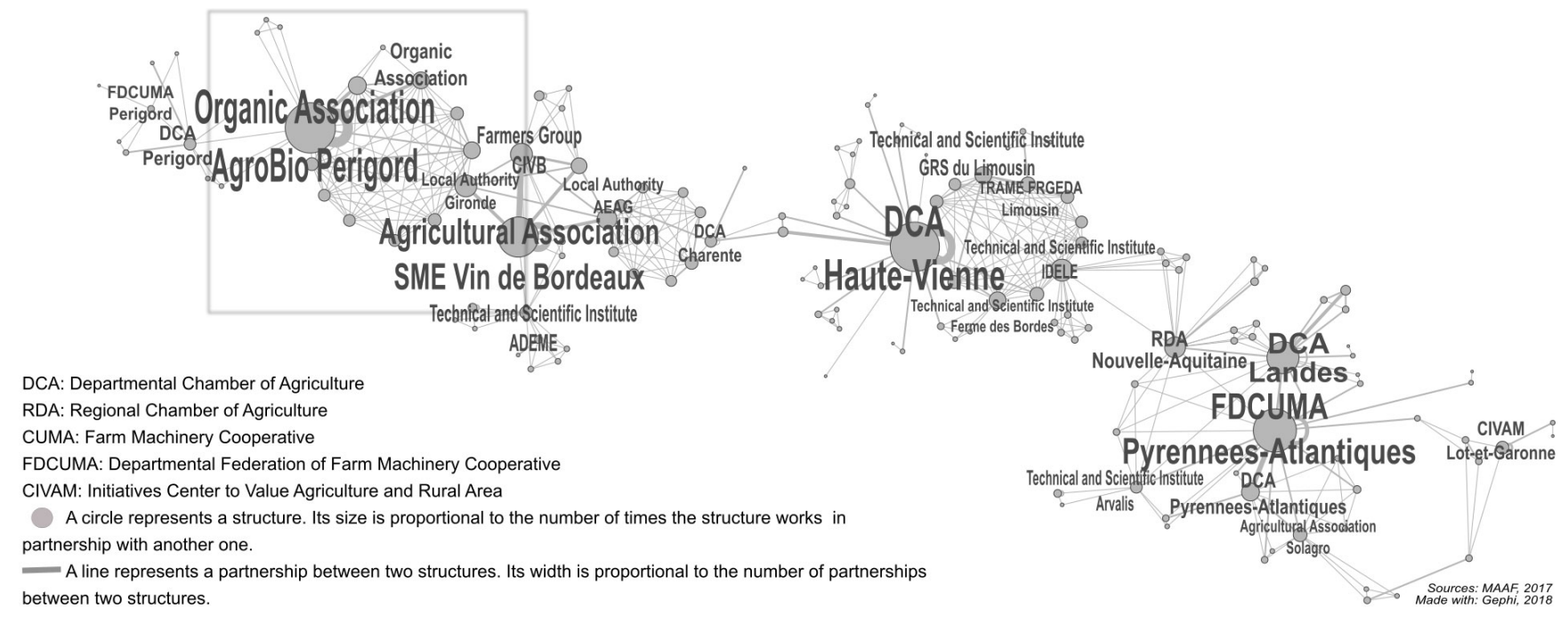

structures specializing in agricultural issues. Most of these département-scale networks are also largely made up of agencies within the agricultural sector (upstream or downstream marketing, research, training, support, etc.) as in the example of the network set up in the Haute-Vienne département.

With the exception of the Chambers of Agriculture, the two instruments involve distinct networks of players. To date, no GIEE has led an AECS even though the 2017 call for projects in the Nouvelle Aquitaine region sees them as potential project developers. Regardless of their official position (partners, leader, outreach organization, and players building on results), the GIEE mainly involve players directly linked to the agricultural sectors while the great majority in AECS are environmental associations and local authorities. The sociogram combining the players involved in both instruments (Fig. 2) clearly demonstrates this, particularly in the Limousin and Aquitaine areas. The Chambers of Agriculture are the main players involved in both instruments. They link the complex network of players working around an AECS with those adopting the GIEE approach. The legacy reflected in the very design of the two systems is therefore passed on in the profile of the structures that have adopted them. In actual practice, however, the two instruments converge, in particular through the collaboration that emerges around the implementation of projects.

\section{Territorialization of the instruments as a factor of} decompartmentalization

The territorialization of these instruments leads to a decompartmentalization of agriculture whose originality is that it is being held from the agriculture sector itself, to the point that we can speak of an integration of environmental issues in the agricultural sector concerns, something Brenac (1988) names as a "corporatization" of the environmental issue. 
Fig. 8. The GIEEs (groupements d'intérêt écologique et économique, or economic and environmental interest groups) network in Dordogne (2017).

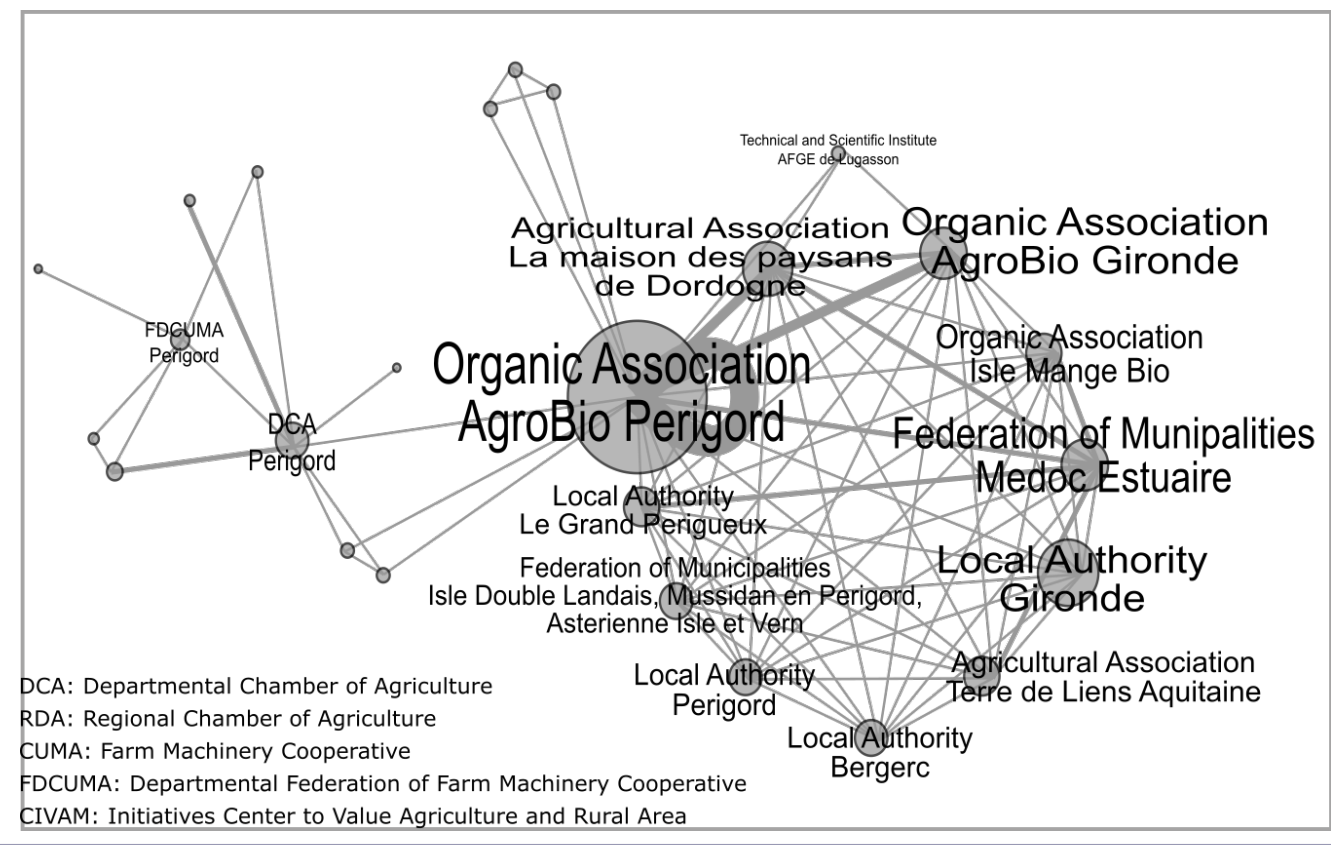

A farmer-driven desectorization of agroecology at local scales Although extension work on the ground is essentially carried out by para-agricultural agencies, nearly $22 \%$ of GIEEs work in collaboration with local players from outside the agricultural sector (Fig. 8). Local authorities (municipalities, municipal federations, départements, and regions) represent $50 \%$ of these partners. Others include regional nature parks, SIVU (management agencies for drinking water supplies, waste collection, and treatment and road maintenance), or devolved state agencies such as the regional offices for agriculture, environment, and housing (DREAL).

The Périgord département gives a good example of the territorial attachment of GIEEs. On the one hand, an association working to develop organic farming, AgroBio Périgord, maintains links with scattered groups of para-agricultural agencies with which it works from time to time (Dordogne Chamber of Agriculture, Toulouse-Purpan school of agriculture and food-processing), or which seem to work in parallel (FDCUMA). On the other hand, AgroBio Périgord is also part of a network of agencies, essentially local authorities, all of which interact with each other. There are various reasons for of local authority involvement in these systems: developing local food supply circuits, relocating collective catering, maintaining landscapes and farming activities, maintaining an attractive recreational living environment, supporting local development, and preserving the quality of drinking water. They are also mainly involved in projects seeking to attract new farmers, to develop new agricultural sectors (especially around energy), or to facilitate links between farmers (exchanges, pooling). Although the GIEEs seem largely based on a sectoral approach at the regional level, locally there are many cases of collaboration between multiple players in different fields of action. Environmental organizations are the main absentees in this system, but the involvement of the local authorities still reflects a certain pattern of desectorization and attachment to local areas as a whole.

A desectorization of AECS driven by environmental associations and local authorities

These patterns are reversed in the case of the AECS. Although local authorities and environmental associations are at the heart of the scheme, AECS often involve economic players. Our analysis of the networks of managing and outreach organization in AECS projects in the Nouvelle Aquitaine region shows this quite clearly (Fig. 3). Not only do economic players regularly appear as partners $(19 \%)$, they also participate in extension work on the ground ( $9 \%$; Fig. 4), while the involvement of Chambers of Agriculture in this area is declining (they are involved in extension work for $28 \%$ of AECS and as project managers for 38\%). The involvement of water management agencies is also declining to the benefit of environmental organizations (LPO, CEN, etc.) but also of many local economic players such as agricultural cooperatives. This is particularly the case in the Poitou Charentes département, where local agricultural cooperatives and an agricultural trading company are partners of a large number of AECS. This is where the role of these organizations in farm assessments can be discerned. Because they can be considered as the main intermediaries for farmers with whom they have a relationship of trust, those managing AECS also involve these organizations in implementing AECMs. Para-agricultural agencies other than Chambers of Agriculture (especially the CIVAM and CUMA, and organic farming associations) are also present ( $17 \%$ of partners) and also participate in extension work (12.5\% of organizers), especially outside the Poitou-Charentes. As partners they are often involved locally in funding for certain activities or in organizing and participating in awareness days. 
Fig. 9. Themes appearing in GIEEs (groupements d'intérêt écologique et économique, or economic and environmental interest groups) in Nouvelle Aquitaine (2017).

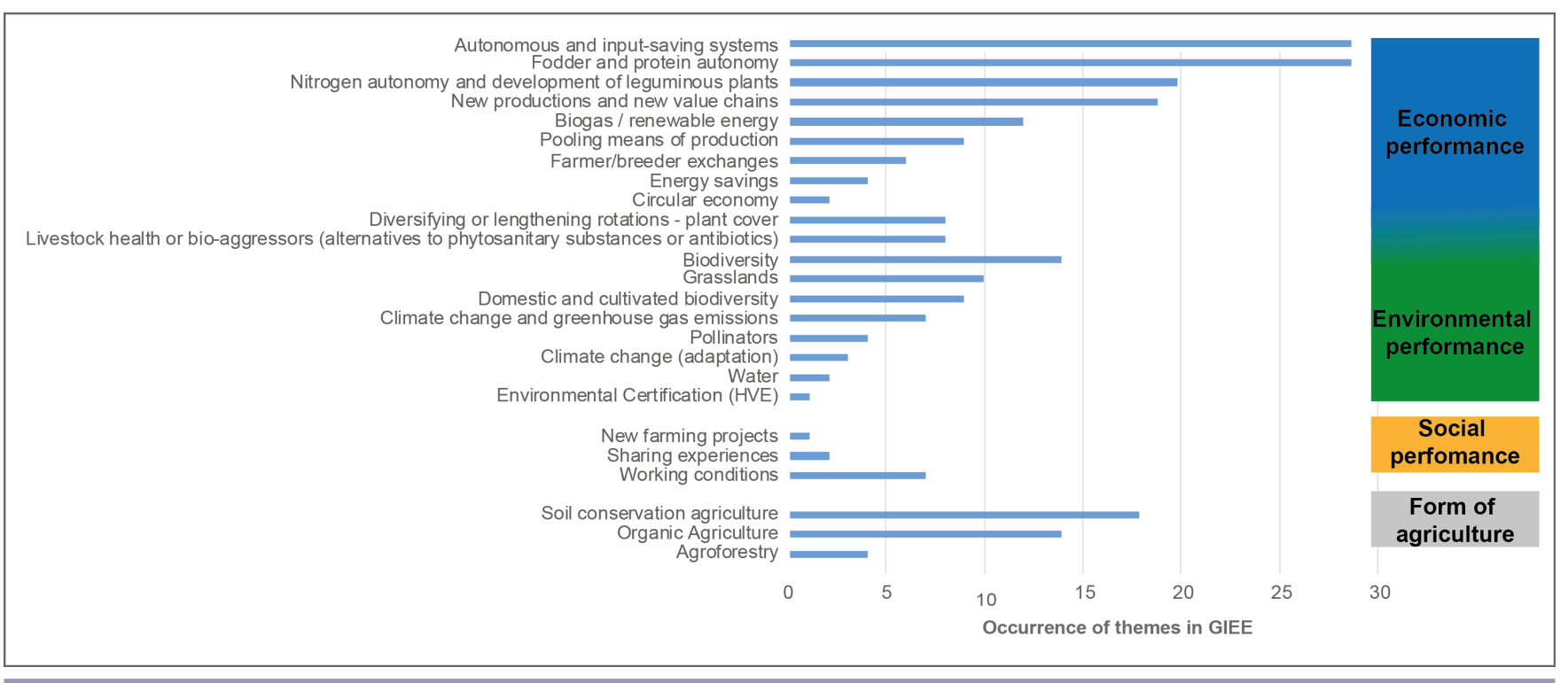

This is the case for CUMAs, which sometimes organize open days and demonstrations of farm machinery.

Although their origins in two different spheres of action are reflected in the way the two instruments are presented and developed, bridging approaches can appear locally. Many players in different fields of expertise (biodiversity, water, economics, planning, etc.) work together to implement these instruments, in both cases reflecting a process of desectorization.

Projects and players joining forces in interlinked spheres of action In practice, the two distinct spheres of action appear to converge through the interweaving of the two instruments that local players see as complementary. Some AECS thus become integrated into GIEEs, particularly in départements where AECS cover large areas. This situation is particularly apparent in the regional nature parks (PNR Périgord-Limousin and PNR Millevaches), in the Haute-Vienne département, and in the three départements of Poitou-Charentes where many players are involved in both instruments (Fig. 2). In the Haute-Vienne, the Chamber of Agriculture has already proposed many AECMs covering quite large areas. One of its departments that has focused specifically on agroecology since 2015 opened an AECS covering the entire département (except the park area) and now has nearly $15 \%$ of all GIEE in New Aquitaine. In Poitou-Charentes, the organizations involved in the management of AACs or Natura 2000 zones adopted CASDAR schemes as early as 2013 to protect sensitive areas. To do so, they developed projects to acquire data on crop and livestock associations, applied conservation agriculture principles (no-till, winter cover), maintained extensive farming, or developed new sectors of activity. In these areas, where agrienvironmental approaches have been in use for several decades, the agroecology concept offers new tools that make it possible to aim for more than due care or due results alone by encouraging the implementation of collective projects that seek to innovate.
The Charente wetlands are a good example of potential bridging projects. Since the 1990s, local stakeholders (LPO, NatureEnvironment, Chamber of Agriculture) trying to maintain farming activities that can preserve these specific and agriculturally unattractive environments have been using AEMs as a means to encourage sheep farmers to maintain the environment by keeping their flocks there. Based on specifications drawn up according to local features, these AEMs have to make it possible to generate an income for farmers who implement practices that help to preserve nesting birds, insects, flora diversity, soil structure, or iconic species (no fertilizer use, delayed mowing or grazing, livestock numbers according to carrying capacities). From the outset, the dynamics built up over time around the GIEE instrument have brought local players to reflect more globally on the future of a profession that is particularly concerned with issues relating to succession. Complementing the incentives introduced since the 1990s, the GIEE have come to open up new prospects by triggering a collective movement, supported by municipal federations around the Marennes Basin and by the Chamber of Agriculture, aiming to group livestock farmers together "around the identity of the Brouage wetlands" and to achieve "technical optimization of farming systems in wetlands" and "the promotion of products from their livestock farming activities" (GIEE project aims).

AECM zones can sometimes complicate the emergence of agroecology-based projects because they are ill regarded in some segments of the agricultural world. However, in areas that have been involved in agri-environmental activities for many years, familiarity between local stakeholders (farmers but also various agencies working in the local area) and their in-depth knowledge of local issues can, on the contrary, drive synergies and new local dynamics and projects in agroecology areas. The fact that the AECS are based on zoning and led by one or more local players revives the principle of a "territorialized" agricultural council that 
had often been abandoned for decades by Chambers of Agriculture (Esposito-Fava 2010) despite being recognized by many researchers as favorable to the introduction of agrienvironmental policies in local areas.

\section{From farm to territory: instruments with distinct objectives} converge when applied in practice

Ultimately, synergies emerge when objectives and issues are defined locally. Our study of the content of projects (Fig. 9) led by GIEE-labeled groups in Nouvelle Aquitaine clearly shows a systematic desire for involvement in the triple performance goal, which is the key criterion for eligibility. But over and above these discussion points, achieving greater autonomy and optimizing production processes appear to be fundamental aims in most projects. These aims are seen as essential to increase farmers' room for manoeuvre, but especially to reduce their working time and increase profit margins, and the means of achieving them are based on three principles of action. The first is to add as much value as possible to production through new technical means or income diversification. Value can be generated from new activities on the farm or using the potential of previously disregarded resources (energy production for example). The second is based on increasing the added value of products by reducing the number of intermediaries (short food supply circuits) or opening up new and more profitable sectors, particularly organic farming. The aims of the latter include reducing costs by pooling purchases of equipment and limiting inputs (phytosanitary products, fertilizers, purchased fodder, seeds, protein supplements, etc.), but they are also environmental: biodiversity conservation, promoting the diversity of plant varieties, and climate change adaptation or mitigation are often brought to the fore. But the different ecosystem components, for example, soil, are often integral to projects in any case because of the role they can play in optimizing production processes.

Here we find a convergence of views with the ecosystem services approach, where the ecosystem is conceived as a provider of services to production and therefore to humanity. On the other hand, protection of the environment rarely appears as a main goal of the projects and never as the sole objective. In other words, biodiversity is not considered as a common good that must be preserved by specific practices but rather as the result of appropriate practices that can be a factor of production among others, providing services to humanity but above all to farmers themselves. In many cases, protecting the environment is only one means (and not a single end) to achieve a wider purpose: to trigger a transition that will transform the model established during the second agricultural revolution and to move toward more autonomous and efficient systems that preserve the environment.

As for the AECS, a quick reading could suggest that maintaining or implementing practices that determine the quality and richness of an environment, and even the presence of certain species or habitats, are the only reason for involvement in these projects (as shown by the list of AECMs). However, several different motivations can be discerned. Some AECS, usually small or at least targeted to a particular environment, are designed strictly for the preservation of certain environments. The AECMs are used to offset the financial losses that arise from limiting environmental impacts or maintaining an agricultural activity on difficult (from the production point of view) soils. Others seek on the contrary to "improve the agroecosystem" via "the creation of biodiversity reservoirs favorable to agronomy" (AECS "Plaine Brioux-Chef-Boutonne," Deux-Sèvres). Rather than opposing agricultural and environmental objectives, they seek to favor biodiversity-rich environments that could usefully complement other farmed areas (Nettier et al. 2012). These AECS generally include one or more AECMs, which are then no longer based on abiding by certain practices but on results (in terms of the number and types of plants present, for example, under the Herbe_07 grassland conservation commitment), allowing "more flexibility in the technical farming system and returning farmers to their role as managers and sole decision-makers regarding practices to be implemented and adjusted to achieve the desired result" (Plantureux et al. 2011:272). This type of logic chimes in well with some key principles of agroecology: giving farmers more room for manoeuvre, recognizing their specialized knowledge, and making use of ecological processes to drive production.

In these AECS, finally, socioeconomic and territorial issues are considered to be the driving forces of the project. The schemes are generally located in difficult environments from the productive point of view (salt marshes, mountain areas, extensive farming areas) and reflect a willingness to maintain agricultural activities in areas that could otherwise be abandoned. Interactions between farming and other sectors of activity (tourism in particular) and the role of agriculture in maintaining employment, populations, and in local development more generally are clearly underlined as key issues for these projects: "The challenge of the Natura 2000 project in this area is to reconcile natural heritage conservation with maintaining and promoting sustainable livestock and forestry development and new leisure and tourism activities" (Micro-AECS Site Natura 2000 du Massif du MondarrainArtzamendi). We find here the choice made by France, and underlined by many authors, to make the AECS system an instrument of public policy for restoring the balance between local areas (Facchini 1999) and maintaining livestock farming (Deverre and De Sainte Marie 2008).

Although they are strictly based on maintaining or improving agricultural practices on the scale of plots or farms, some AECS, paradoxically, contribute to more ambitious territorial objectives than the GIEE. This finding can be explained by the fact that they are based on zoning, require a diagnosis of the local area (often very succinct), and are often promoted by players with authority that extends beyond the strictly agricultural sphere. In practice, however, the resources used (AECM) are still strictly targeted to agricultural practices. Although they sometimes make it possible to reason on the scale of the entire operating systems (only the "systemic" AECMs concern entire farms, with localized AECMs targeted to certain parcels), unlike the GIEE they never offer the possibility of developing localized production or food systems.

The AECS therefore sometimes reflect territorial issues but only allow action on the scale of farm plots. The GIEE system, on the other hand, tends to focus on farmers' autonomy by optimizing production processes, although it does offer possibilities for action on the scale of a local area, such as short food supply circuits, but the area is neither delineated nor supported as such by local authorities. 


\section{DISCUSSION: TWO DIFFERENT PATHWAYS TO A SAME GREENER AGRICULTURE}

AECM are used to compensate for failures to protect sensitive or abandoned natural areas by reducing farming intensity or maintaining certain farming activities. The other aims to trigger a shift in the dynamics of agriculture. The two instruments are driven and funded by different political players: the AECMs are European instruments managed by France, while the GIEEs are the spearhead of French green agriculture policy. Apart from the Chambers of Agriculture, the two instruments also involve different players: from outside the world of agriculture for the AECM, para-agricultural organizations for the GIEE. Logically, the two instruments occupy different spaces, and almost mirror one another: the AECM in areas where the environmental stakes are high, agroecology in areas dominated by conventional agriculture.

Indeed, we find that these instruments contribute to the desectorization of agriculture in two ways. First, local authorities are increasingly taking over agricultural issues. They take part in schemes that affect the agricultural sphere beyond the three areas in which they exercise their authority (local circuits and land or drinking water management). Second, agriculture is increasingly working with the nature conservation community, especially in the case of the AECMs. This desectorization process is particularly evident at the very local level, where topographical and topological metrics meet and encompass ecologically sound agriculture as part of the rural world. But the fact that agricultural organizations are nevertheless very present in projects that emerge, or even totally dominate one of the two instruments (the GIEE), testifies to a certain form of "corporatization" (Brénac 1988) of the problem inherited from the sectoral corporatism that characterizes French policies (Jobert 1985, Brénac 1988, Muller 1990). Whereas in other countries (England especially) agrienvironmental issues are the realm of environmental charities/ ecologists, in France, agricultural and para-agricultural organizations are powerful enough to tackle environmental issues.

These differences follow logically from the intellectual history of each instrument and are to be expected. But the contrast between the agroecology and ecosystem services concepts tends to fade when we analyze how each of these instruments is put in place. The changes to agriculture brought by the two instruments tend to converge toward the same result and this is convenient with the way instruments function. Both share a greater embeddedness (territorialization) in local contexts, i.e., (1) strengthening the importance of administrative local scales, (2) opening the agrarian issues to actors coming from outside agriculture (Muller 1990, Duran and Thoenig 1996), and (3) broadening debates through participatory and procedural instruments (Lascoumes and Bourhis 1998). It leads to the proposal of adjustable procedures, influenced by the territory that seizes it, which obeys its own logic, depending on the actors that implement them (Lascoumes and Le Gales 2004).

Although both instruments try to limit the impacts of agriculture and are part of the greener farming movement that has been developing since the 1990s, they are also driving a process of opening up agriculture to other sectors. Many of the transformations of agriculture we described with our data have already been identified by Pierre Muller during the 1980s (Muller 1990) and others afterward (Berriet-Solliec et al. 2009, EspositoFava 2010, Hervieu and al. 2010). French agriculture was known for its highly sectoral mode of organization based on comanagement between the state and agricultural unions, with a very active majority union at all scales from the Ministry to the Chambers of Agriculture in each département. French agriculture was transforming itself according to a dynamic of desectorization and territorialization driven by the transformation of the French and European contexts. Since then, these dynamics have deepened with the different crises (environmental, sanitarian, economic) agriculture faced and with the evolution of the European policies (Fouilleux 2003, Ansaloni and Fouilleux 2008, Ansaloni 2015).

But what our data suggest is that this movement is now coming from the agricultural sector itself. The movement does not come, as until now, from outside agriculture, but from agricultural institutions themselves. The territorialization of public action, in the agricultural sector indeed "at first, nourished generalist devices" (contracts of city-average, country, LEADER, PNR) and seized "of the agriculture through its derived products: the management of space, the environment or the organization of urban development" (Esposito-Fava 2010:411). The evolution of the current instruments comes from the internalization of territorial public action by the agricultural sector itself, whereas until now the territorial action was calling the agricultural sector. In addition to the generalized territorialized instruments that existed previously and continue to strengthen (CEAPS), the range of tools specific to the agricultural sphere is expanding and opens up more diverse and procedural forms of collective action. Instruments based on zoning of space and a relatively strict framing defined by the EU or by the state (the CEAPs built their project within a strictly delimited perimeter and on the basis of a list of defined measures by the EU), are thus complemented by more adjustable procedures and impulses of grid-like association logic that offer actors much greater freedom of interpretation and action without zoning constraints. Local governance of agricultural issues thus supplants local government (Muller 1990), allowing para-agricultural structures as well as local and regional authorities to seize environmental issues not only with a view to local development but in a transition of the agricultural sector. The French Ministry of Agriculture and the European Union incentivize farmers to build partnerships with local authorities, environmental association, etc., to incorporate territorial and environmental issues. Finally, both instruments play the same role.

Another convergent trend stems from the aim of increasing income by offsetting the failures of an insufficiently remunerative market and capturing some of the production margins. This means diversifying sources of income (via energy production, opening up new sectors, or payment for environmental services). In the GIEE, this trend appears both upstream, in systems for pooling agri-supplies or machinery, which are a prominent feature in the GIEE, and downstream, with the aim of shortening circuits in order to increase margins or diversify production systems. The same logic is found, as we have seen, with the AECM, which offers a source of additional income.

These convergences are the main new finding from our analyses. As instruments aiming to promote greener agriculture, the AECM 
and GIEE converge to drive a dynamic of transition. This result can be interpreted in the light of three points discussed in this paper.

The transition dynamic can be analyzed as moving toward a reconciliation of technological approaches based on controlling natural processes and applied to increasingly local scenarios; this could be expressed, as stated in the AEM, as a shift from the TechnoGarden scenario to the principles of the adaptive mosaic scenario. The ecosystem services and agroecology concepts then fully come into their role as frontier objects. They allow a shift in conventional systems, timid and incomplete, but nevertheless real, toward ecological modernization and greener agriculture. These instruments also fulfil a function of reconciling the opposition between "land sparing" and "land sharing" (Green et al. 2005, Fischer et al. 2008). The spatial distribution of the two instruments shows a mirror pattern, one intended for areas where the environmental stakes are high and the other for productive areas, which may suggest a specialization of spaces corresponding to a specialization of instruments. But in their respective spaces, both tend to result in greener productive dynamics. In this sense, they can be seen as instruments that promote a renewal of the land sparing approach that no longer opposes conservation to production areas but seeks to establish greener practices in areas of conventional agriculture (Fischer et al. 2014).

Furthermore, the two concepts have themselves evolved and shifted away from their respective goals. The ecosystem services concept has increasingly focused on factors of synergy and tradeoffs between services (Bennett et al. 2009), particularly in agriculture (Lescourret et al. 2015), which highlights the complex relationships between the two (Norgaard 2010). At the same time, the traditional link between ecology and agronomy, which lies at the heart of agroecology, is still present and even becoming stronger (Wezel et al. 2009, Wezel and Soldat 2009), even though many fundamental points of agroecology, as seen by numerous authors, have not been found in the cases studied.

Finally, the GIEEs and, to a lesser extent the AECS, advocate innovation based on exchanges between peers and developing farmers' knowledge through experimentation. Farmers are thus encouraged to join forces to innovate.

However, the strength of these trends in agricultural modernization has to be brought into perspective on three levels at least. First, because, unlike innovations achieved by incorporating something new, these innovations are introduced by reducing or withdrawing a given practice (Goulet and Vinck 2012). They represent a critique of the dominant system, bringing in new players to justify the implementation of innovations, reviving or enhancing farmers' knowledge, and creating synergies between known or new techniques. Although these characteristics echo the principles of agroecology, they do not place ecosystem processes at the heart of production systems, aiming instead for substitution. The kind of agriculture that these withdrawals are establishing more closely resembles conservation agriculture or organic agriculture than agroecology (Bellon et al. 2011), which is convenient with the current transformation of the CAP (Erjavec and Erjavec 2015).

Furthermore, these systems are not quantitatively robust. The 83 GIEE in place in 2017 represent just 1500 (DRAAF New-
Aquitaine) of around 70,000 farms identified in New-Aquitaine $(2 \%)$ and only 5000 farms were engaged in one or more AECMs, thas is, say 7\% of New-Aquitaine farms. The total 2014-2018 amount of the AECMs was estimated at 224.5 million euros of public credits while other CAP aids (excluding AECM and aids to organic farming) represented 1.2 billion euros in New Aquitaine for the year 2017 (source: DRAAF 2017, DRAAF 2018, DRAAF 2019, AGRESTE 2018). This is reflected in the systemic difficulties France is facing to reduce its dependence on plant protection products (Charbonnier et al. 2015).

Finally, the system is contested on at least two levels. First by the majority of farmers who see environmental instruments as illegitimate constraints. The idea of agroecology itself is contested, precisely because it is about ecology. But there are also criticisms from the world of agroecology, which considers that the scientific dimension of agroecology is shifting it away from the initial social aims. These criticisms are found in social movements and among some of the scientists who represent them (Pérez-Vitoria 2010, Sarandon and Flores 2012, Sevilla-Guzmán and Woodgate 2013).

\section{CONCLUSION}

French agriculture, as many others, is in a tense situation. It is contested by national societies with environmental and health issues. But these arguments are, on their own, contested within the agricultural sector that does not officially recognize their legitimacy. In this tense context, ecosystem services and agroecology are used by the EU and the French Ministry of Agriculture as vague public policies categories to pave the way for policy instruments (GIEE and AEPC), which aim at a greener agriculture. Farmers themselves appropriate these instruments to diminish their impact on the environment through agricultural conservation practices, to reach more autonomy, and to build new relationships with public authorities and environmental associations.

Of course, these instruments are contested by different segments of the agricultural sector and have little weight in comparison to conventional instruments. But they are also designed to help conventional systems move toward greater integration in the socio-political territories in which they operate, toward greater autonomy and less dependence on phytosanitary products. They are helping to shift farming toward forms of agriculture that are closer to conservation agriculture than to agroecology per se.

The two instruments described here place particular emphasis on territorial dimensions. Both were designed to be adaptable to particular territories in accordance with the logic of local politics, with production policies with the specific features of the local environment. Both are essentially sketching out pathways for agricultural renewal. Their technical dimensions are more discreet, mainly involving withdrawal, but this withdrawal in itself transforms practices and calls for new knowledge. Above all, the integration within the agricultural sector of the two tools (especially the GIEE) shows that some segments of the agricultural sector are reconciling with their territory.

Ultimately, their aims, but also their weaknesses, bring the multidimensional nature of agriculture to the fore: agriculture is linked to the environment, and the call for ecology is a manifestation of this; but it is also political and social, which is 
evident when political players promote instruments to bring about change by bringing in new social and political players; it is technical, when it calls for transformations of production systems; and it is social, when it calls for acceptance by the population.

${ }^{[1]}$ AECS are regional projects that set out specific objectives for some local areas. AECMs (agri-environment-climate measures) are the financial instruments that support these projects.

${ }^{[2]}$ Until the merger in 2016, each of the three former regions of Nouvelle Aquitaine launched its own calls for AECS and GIEE projects.

${ }^{[3]}$ Some GIEEs are defined for an entire département. We have not represented them here to avoid blurring the information. We applied the same methodology for the AECM Systems.

${ }^{\text {[4] }}$ The 10 criteria for assessing a GIEE, according to the French Ministry of Agriculture (DRAAF 2016): (1) "Economic performance," correlating with "autonomy"; (2) "Environmental performance"; (3) "Social performance" (4) "Technical relevance of planned actions": "the modification or consolidation of practices ... should be based on the principles of agroecology"; (5) "Collective character of the planned actions": the advantages of group action over individual action have to be demonstrated; (6) "Relevance of the partnerships": farmers have to seek as many partners as possible among sectoral, territorial, and civil society players; (7) "Innovative character - importance of experimentation"; (8) "Duration and sustainability of the project"; (9)"Support methods for farmers"; (10) "Exemplary character": reproducibility of the project.

${ }^{[5]}$ France is organized administratively into four different levels: national, regional (France is now divided into 13 regions instead of 22 before 2014), the département level, which subdivides the country into 90 départements, and the municipal level (France has roughly 36,000 municipalities). The latter can be grouped into municipal federations that exercise some of the municipal legal authority. The GIEE and AECS are organized at the regional scale, while each département has its own Chamber of Agriculture.

${ }^{[6]}$ AAC, Aires d'alimentation de captage, are the areas around water supply and abstraction points that have to be protected to preserve water quality.

[7] The Chambers of Agriculture are institutions devoted to agricultural development at the département level. They are directed by farmers elected from trade union lists and represent the interests of farmers at the local scale.

${ }^{[8]}$ The CIVAM (Centres d'initiatives pour valoriser l'agriculture et le milieu rural are not-for-profit groups dedicated to rural and agricultural development. They often work closely with smallholder farming movements, and promote closer links between farmers and inhabitants of rural or urban areas, especially through local food distribution systems.

[9] The CUMA (Coopérative d'utilisation de materiel agricole) are cooperatives running a pool of agricultural machinery purchased and shared by farmers in their local area.

${ }^{[10]}$ The CIVU (Syndicat intercommunal à vocation unique) are set up by local authorities to provide a specific service.

${ }^{[11]}$ The Conservatoire des espaces naturels $(\mathrm{CEN})$ are not-for-profit associations working with multiple stakeholders (state, private, voluntary) to preserve biodiversity and foster sustainable management practices.

${ }^{[12]}$ Ligue de Protection des Oiseaux
${ }^{[13]}$ The regional nature parks (PNR) are protected areas dedicated to the conservation and development of large inhabited rural areas where specific heritage, cultural, and environmental issues are at stake. There are 52 PNR in France, covering $15 \%$ of the entire country.

Responses to this article can be read online at: http://www.ecologyandsociety.org/issues/responses. php/10711

\section{LITERATURE CITED}

AGRESTE. 2018. Le bilan annuel de l'emploi agricole. Résultats 2016 et estimations 2017. Agreste Chiffres et Données: Série Agriculture 253. [online] URL: http://agreste.agriculture.gouv.fr/ IMG/pdf/agri253BAEA fev2019 sommaire.pdf

Allaire, G. 2016. Que signifie le “développement” de l'agriculture biologique? Innovations Agronomiques 51:1-17.

Allaire, G., E. Cahuzac, T. Pomeon, and M. Simoni. 2014. Approche spatiale de la conversion à l'agriculture biologique. Economie Rurale 339-340:9-31.

Altieri, M. A. 1987. Agroecology: the scientific basis of alternative agriculture. Westview, Boulder, Colorado, USA.

Altieri, M. A. 1995. Agroecology: the science of sustainable agriculture. CRC, Boca Raton, Florida, USA. http://dx.doi. org/10.1201/9780429495465

Ansaloni, M. 2015. Le tournant environnemental de la Politique Agricole Commune. L'Harmattan, Paris, France.

Ansaloni, M., and E. Fouilleux. 2008. Terroir et protection de l'environnement: un mariage indésirable? A propos d'intégration de critères environnementaux dans un instrument de politique agricole. Politiques et Management Public 27(4):3-24.

Ansaloni, M., and V. Tournay. 2013. Les instruments de résistance comme composants transitoires et évolutifs de l'intégration européenne. L'exemple de la politique agricole commune. Quaderni 80:47-59. http://dx.doi.org/10.4000/quaderni.671

Barnaud, C., and M. Antona. 2014. Deconstructing ecosystem services: uncertainties and controversies around a socially constructed concept. Geoforum 56:113-123. http://dx.doi. org/10.1016/j.geoforum.2014.07.003

Beck, U. 2016. The metamorphosis of the world. Polity, Cambridge, Massachusetts, USA.

Beck, U., A. Giddens, and S. Lash. 1994. Reflexive modernization: politics, tradition and aesthetics in the modern social order. Stanford University Press, Stanford, California, USA.

Bellon, S., C. Lamine, G. Ollivier, and L. S. de Abreu. 2011. The relationships between organic farming and agroecology. IFOAMISOFAR Korean Organic World Congress, September 2011:235-238.

Bennett, E. M., W. Cramer, A. Begossi, G. Cundill, S. Díaz, B. N. Egoh, I. R. Geijzendorffer, C. B. Krug, S. Lavorel, E. Lazos, L. Lebel, B. Martín-López, P. Meyfroidt, H. A. Mooney, J. L. Nel, 
U. Pascual, K. Payet, N. P. Harguindeguy, G. D. Peterson, A.-H. Prieur-Richard, B. Reyers, P. Roebeling, R. Seppelt, M. Solan, P. Tschakert, T. Tscharntke, B. L. Turner II, P. H. Verburg, E. F. Viglizzo, P. C. L. White, and G. Woodward. 2015. Linking biodiversity, ecosystem services, and human well-being: three challenges for designing research for sustainability. Current Opinion in Environmental Sustainability 14:76-85. http://dx.doi. org/10.1016/j.cosust.2015.03.007

Bennett, E. M., G. D. Peterson, and L. J. Gordon. 2009. Understanding relationships among multiple ecosystem services. Ecology Letters 12:1394-1404. http://dx.doi.org/10.1111/ j.1461-0248.2009.01387.x

Bensin, B. M. 1928. Agroecological characteristics description and classification of the local corn varieties chorotypes. [Publisher unknown].

Berriet-Solliec, M., A. Le Roy, and A. Trouvé. 2009. Territorialiser la politique agricole pour plus de cohésion. Économie Rurale 313-314(5-6):129-146.

Berti, A. 2017. GIEE en nouvelle aquitaine. Mémoire de master géographie aménagement sociologie. Université de Pau et des Pays de l'Adour, Pau, France.

Biggs, R., M. Schlüter, D. Biggs, E. L. Bohensky, S. BurnSilver, G. Cundill, V. Dakos, T. M. Daw, L. S. Evans, K. Kotschy, A. M. Leitch, C. Meek, A. Quinlan, C. Raudsepp-Hearne, M. D. Robards, M. L. Schoon, L. Schultz, and P. C. West. 2012. Toward principles for enhancing the resilience of ecosystem services. Annual Review of Environment and Resources 37(1):421-448. http://dx.doi.org/10.1146/annurev-environ-051211-123836

Bonacich, P. 1987. Power and centrality: a family of measures. American Journal of Sociology 92(5):1170-1182. https://doi. org/10.1086/228631

Bonnal, P., M. Bonin, and O. Aznar. 2012. Les évolutions inversées de la multifonctionnalité de l'agriculture et des services environnementaux. VertigO 12(3). https://doi.org/10.4000/ vertigo. 12882

Brénac, E. 1988. Corporatismes et politiques intersectorielles: la politique de l'environnement. Pages 127-146 in D. Colas, editor. L'Etat et les corporations. PUF, Paris, France.

Buttel, F. H. 2000. Ecological modernization as social theory. Geoforum 31(1):57-65. http://dx.doi.org/10.1016/S0016-7185(99) $\underline{00044-5}$

Caillaud, K. 2015. Les logiques contingentes des politiques départementales de sécurisation de l'eau potable. Géographie, Économie, Société 17(3):315-337.

Caporali, F. 2011. Agroecology as a transdisciplinary science for a sustainable agriculture. Pages 1-71 in E. Lichtfouse, editor. Biodiversity, biofuels, agroforestry and conservation agriculture. Springer, Dordrecht, The Netherlands. http://dx.doi. org/10.1007/978-90-481-9513-8 1

Charbonnier, E., A. Ronceux, A.-S. Carpentier, H. Soubelet, and E. Barriuso. 2015. Pesticides: des impacts aux changements de pratiques. Quae, Paris, France.
Chatellier, V., and H. Guyomard. 2011. Le bilan de santé de la PAC et le réééquilibrage des soutiens à l'agriculture française. Economie Rurale 323:4-20. https://doi.org/10.4000/economierurale.3021

Clausen, R., and S. B. Longo. 2012. The tragedy of the commodity and the farce of AquAdvantage Salmon ${ }^{\circledR}$. Development and Change 43(1):229-251. http://dx.doi.org/10.1111/j.1467-7660.2011.01747. $\underline{\mathrm{x}}$

Costanza, R., R. d'Arge, R. de Groot, S. Farber, M. Grasso, B. Hannon, K. Limburg, S. Naeem, R. V. O'Neill, J. Paruelo, R. G. Raskin, P. Sutton, and M. van den Belt. 1997. The value of the world's ecosystem services and natural capital. Nature 387:253-260. http://dx.doi.org/10.1038/387253a0

Cox, G. W., and M. D. Atkins. 1979. Agricultural ecology: an analysis of world food production systems. W. H. Freeman, San Francisco, California, USA.

Daily, G. 1997. Nature's services: societal dependence on natural ecosystem. Island, Washington, D.C., USA.

Dempsey, J., and M. M. Robertson. 2012. Ecosystem services: tensions, impurities, and points of engagement within neoliberalism. Progress in Human Geography 36(6):758-779. http://dx.doi.org/10.1177/0309132512437076

Deverre, C., and C. De Sainte Marie. 2008. L'écologisation de la politique agricole européenne. Verdissement ou refondation des systèmes agro-alimentaires. Revue d'Etudes en Agriculture et Environnement 89(1):83-104.

Douillet, A.-C. 2003. Les élus ruraux face à la territorialisation de l'action publique. Revue Française de Science Politique 53 (4):583-606. http://dx.doi.org/10.3917/rfsp.534.0583

Douillet, A.-C., E. Négrier, and A. Faure. 2015. Trois regards sur les politiques publiques vues du local. Pages 319-348 in L. Boussaguet, S. Jacquot, and P. Ravinet, editors. Une "French touch" dans l'analyse des politiques publiques? SciencesPo Les Presses, Paris, France.

DRAAF Nouvelle Aquitaine (Direction régional de l'alimentation, de l'agriculture et de la forêt New-Aquitaine). 2016. Appel à projets régional DRAAF Aquitaine-Limousin-Poitou-Charentes 2016: Reconnaissance de Groupements d'Intérêt Economiques et Environnemental. [online] URL: https://www.google.com/url?sa= $\mathrm{t} \& \mathrm{rct}=\mathrm{j} \& \mathrm{q}=\&$ esrc $=\mathrm{s} \&$ source $=$ web $\& \mathrm{~cd}=1 \& \mathrm{cad}=$

rja\&uact $=8 \& v e d=2$ ahUKEwiIh 5 Svn $-3 \mathrm{gAhXM} 8 \mathrm{uAKHZjgAZQ}$ QFjAAegQIAxAC\&url=http $\% 3 \mathrm{~A} \% 2 \mathrm{~F} \% 2 \mathrm{Fdraaf}$.nouvelle-aquitaine. agriculture.gouv.fr $\% 2$ FIMG $\% 2$ Fpdf $\% 2$ FAAP-GIEE-

ALPC-22-03-2016 cle8386ad.pdf\&usg=AOvVaw1 tuGZ06jViXtsjGbN6Qn76

DRAAF Nouvelle Aquitaine (Direction régional de l'alimentation, de l'agriculture et de la forêt New-Aquitaine). 2017. Synthèse des aides en région Nouvelle-Aquitaine. DRAAF Nouvelle Aquitaine, Limoges, France. [online] URL: http://draaf.nouvelle-aquitaine. agriculture.gouv.fr/IMG/xls/subventions 2017 donnees telechargeables reg cle8c15ab.xls

DRAAF Nouvelle Aquitaine (Direction régional de l'alimentation, de l'agriculture et de la forêt New-Aquitaine). 2018. Commission Agro-Ecologie Nouvelle-Aquitaine du 20 mars 2018: Les 1ers 
Bilans Intermédiaires des GIEE en Nouvelle-Aquitaine. DRAAF Nouvelle Aquitaine, Limoges, France. [online] URL: http://draaf. nouvelle-aquitaine.agriculture.gouv.fr/IMG/pdf/brochure GIEE V19 cle015266.pdf

DRAAF Nouvelle Aquitaine (Direction régional de l'alimentation, de l'agriculture et de la forêt New-Aquitaine). 2019. Appel à projets agroenvironnementaux et climatiques: Déclinaison des programmes de développement rural (PDR) 2014-2020, Aquitaine, Limousin et Poitou-Charentes. DRAAF Nouvelle Aquitaine, Limoges, France. [online] URL: https://www.google.com/url?sa= t\&rct $=j \& q=\&$ esrc $=\mathrm{s} \&$ source $=$ web $\& \mathrm{~cd}=1 \& \mathrm{cad}=$

rja \&uact $=8 \&$ ved $=2$ ahUKEwi0x6yqoe $3 \mathrm{gAhXT} 80 \mathrm{OKH}$ HC1BFUQFjAAegQIBxAC\&url=http $\% 3 \mathrm{~A} \% 2 \mathrm{~F} \% 2 \mathrm{Fdraaf}$.nouvelle-aquitaine. agriculture gouv.fr $\% 2$ FIMG $\% 2$ Fpdf $\% 2$ F 181001 AAP MAEC2019_V1-0_cle8b38a5.pdf\&usg=AOvVaw2R2B7Z8mSBG8 pTXpFthSV

Dubois, V. 1998. Politique culturelle: le succès d'une catégorie floue: Contribution à l'analyse des catégories d'intervention publique. Pages 167-182 in M. Kaluszinski and S. Wahnich, editors. L'État contre la politique. L'Harmattan, Paris, France.

Duran, P., and J.-C. Thoenig. 1996. L'Etat et la gestion publique territoriale. Revue Française de Science Politique 46(1):580-623.

Erjavec, K., and E. Erjavec. 2015. 'Greening the CAP' - just a fashionable justification? A discourse analysis of the 2014-2020 CAP reform documents. Food Policy 51:53-62. https://doi. org/10.1016/j.foodpol.2014.12.006

Esposito-Fava, A. 2010. Territorialisations et action agricole: quelles ressources et dispositifs pour quelles gouvernances? Une analyse à partir des cas du Parc Naturel Régional du Marais du Cotentin et du Bessin, de Métropole Savoie et de Rovaltain. Université Joseph-Fourier-Grenoble I, Grenoble, France.

Facchini, F. 1999. La mise en œuvre de l'article 19 du règlement CEE 797/85 en France et en Grande-Bretagne. Économie Rurale 252:3-9. http://dx.doi.org/10.3406/ecoru.1999.5094

Figadère, M. 2017. La territorialisation des projets agroenvironnementaux et climatiques en Nouvelle Aquitaine. Mémoire de master Géographie Aménagement Sociologie, Université de Pau et des Pays de l'Adour, Pau, France.

Fischer, J., D. J. Abson, V. Butsic, M. J. Chappell, J. Ekroos, J. Hanspach, T. Kuemmerle, H. G. Smith, and H. von Wehrden. 2014. Land sparing versus land sharing: moving forward. Conservation Letters 7(3):149-157. http://dx.doi.org/10.1111/ conl.12084

Fischer, J., B. Brosi, G. C. Daily, P. R. Ehrlich, R. Goldman, J. Goldstein, D. B. Lindenmayer, A. D. Manning, H. A. Mooney, L. Pejchar, J. Ranganathan, and H. Tallis. 2008. Should agricultural policies encourage land sparing or wildlife-friendly farming? Frontiers in Ecology and the Environment 6(7):380-385. http://dx.doi.org/10.1890/070019

Fouilleux, E. 2003. La politique agricole commune et ses réformes. Une politique à l'épreuve de la globalisation. L'Harmattan, Paris, France.

Francis, C., G. Lieblein, S. Gliessman, T. A. Breland, N. Creamer, R. Harwood, L. Salomonsson, J. Helenius, D. Rickerl, R. Salvador, M. Wiedenhoeft, S. Simmons, P. Allen, M. Altieri, C.
Flora, and R. Poincelot. 2003. Agroecology: the ecology of food systems. Journal of Sustainable Agriculture 22(3):99-118. http:// dx.doi.org/10.1300/J064v22n03 10

Gassiat, A., and F. Zahm. 2013. Améliorer la qualité de l'eau: quelle territorialisation? Economie Rurale 333:81-100.

Gliessman, S. R. 2014. Agroecology: the ecology of sustainable food systems. CRC Press, Boca Raton, Florida, USA. http://dx. doi.org/10.1201/b17881

Gomez-Baggethun, E., R. de Groot, P. L. Lomas, and C. Montes. 2010. The history of ecosystem services in economic theory and practice: from early notions to markets and payment schemes. Ecological Economics 69(6):1209-1218. http://dx.doi.org/10.1016/ j.ecolecon.2009.11.007

Gómez-Baggethun, E., and R. Muradian. 2015. In markets we trust? Setting the boundaries of market-based instruments in ecosystem services governance. Ecological Economics 117:217-224. http://dx.doi.org/10.1016/j.ecolecon.2015.03.016

Goulet, F., N. Girard, D. Magda, and V. Hernandez. 2012. L'agroécologie en Argentine et en France. L'Harmattan, Paris, France.

Goulet, F., and D. Vinck. 2012. L'innovation par retrait. Contribution à une sociologie du détachement. Revue Française de Sociologie 53(2):195-224. http://dx.doi.org/10.3917/rfs.532.0195

Granovetter, M. S. 1973. The strength of weak ties. American Journal of Sociology 78(6):1360-1380. http://dx.doi.org/10.1086/225469

Green, R. E., S. J. Cornell, J. P. W. Scharlemann, and A. Balmford. 2005. Farming and the fate of wild nature. Science 307:550-555. http://dx.doi.org/10.1126/science.1106049

Gunderson, L. H., and C. S. Holling. 2002. Panarchy: understanding transformations in human and natural systems. Island, Washington, D.C., USA.

Harreau, A. 2009. Analyse comparative des mesures agroenvironnementales territorialisées à enjeu eau sur trois régions: Aquitaine, Midi-Pyrénées et Poitou-Charentes. Mémoire de fin d'étude ENITAB, Cemagref, Bordeaux, France.

Hervieu, B., N. Mayer, P. Muller, F. Purseigle, and J. Rémy. 2010. Les mondes agricoles en politique. De la fin des paysans au retour de la question agricole. SciencesPo Les Presses, Paris, France.

Jacobs, S., N. Dendoncker, and H. Keune. 2014. Ecosystem services: global issues, local practices. First edition. Elsevier, Amsterdam, The Netherlands.

Jobert, B. 1985. L'Etat en action. L'apport des politiques publiques. Revue Française de Science Politique 35(4):654-682. https://doi.org/10.3406/rfsp.1985.394207

Jobert, B., and P. Muller. 1987. L'etat en action. Politiques publiques et corporatismes. Presses universitaires de France, Paris, France.

Klages, K. H. 1942. Ecological crop geography. Macmillan, New York, New York, USA.

Kull, C. A., X. Arnauld de Sartre, and M. Castro-Larrañaga. 2015. The political ecology of ecosystem services. Geoforum 61:122-134. http://dx.doi.org/10.1016/j.geoforum.2015.03.004 
Lascoumes, P., and J.-P. Le Bourhis. 1998. Le bien commun comme construit territorial. Identités d'action et procédures. Politix 42:37-66. http://dx.doi.org/10.3406/polix.1998.1724

Lascoumes, P., and P. Le Gales. 2004. Gouverner par les instruments. Presses de la Fondation nationale des sciences politiques, Paris, France.

Laurans, Y., A. Rankovic, R. Billé, R. Pirard, and L. Mermet. 2013. Use of ecosystem services economic valuation for decision making: questioning a literature blindspot. Journal of Environmental Management 119:208-219. http://dx.doi.org/10.1016/ j.jenvman.2013.01.008

Lazega, E. 1994. Analyse de réseaux et sociologie des organisations. Revue Française de Sociologie 35(2):293-320. https://doi.org/10.2307/3322036

Lescourret, F., D. Magda, G. Richard, A.-F. Adam-Blondon, M. Bardy, J. Baudry, I. Doussan, B. Dumont, F. Lefèvre, I. Litrico, R. Martin-Clouaire, B. Montuelle, S. Pellerin, M. Plantegenest, E. Tancoigne, A. Thomas, H. Guyomard, and J.-F. Soussana. 2015. A social-ecological approach to managing multiple agroecosystem services. Current Opinion in Environmental Sustainability 14:68-75. http://dx.doi.org/10.1016/j.cosust.2015.04.001

Levidow, L., K. Birch, and T. Papaioannou. 2013. Divergent paradigms of European agro-food innovation: the knowledgebased bio-economy (KBBE) as an R\&D Agenda. Science, Technology, \& Human Values 38(1):94-125. http://dx.doi. org/10.1177/0162243912438143

Levidow, L., M. Pimbert, and G. Vanloqueren. 2014. Agroecological research: conforming-or transforming the dominant agro-food regime? Agroecology and Sustainable Food Systems 38(10):1127-1155. http://dx.doi.org/10.1080/21683565.2014.951459

Loconto, A. 2017. L'agroécologie à la FAO, Seminaire du Groupe de Travail Agro-écologie. French National Academy for Agriculture, Paris, France.

Lowe, P., H. Buller, and N. Ward. 2002. Setting the next agenda? British and French approaches to the second pillar of the Common Agricultural Policy. Journal of Rural Studies 18(1):1-17. https://doi.org/10.1016/S0743-0167(01)00025-0

Maris, V. 2014. Nature à vendre? Les limites des services écosystémiques. Editions Quae, Paris, France.

McAfee, K. 2012. The contradictory logic of global ecosystem services markets. Development and Change 43(1):105-131. http:// dx.doi.org/10.1111/j.1467-7660.2011.01745.X

Millennium Ecosystem Assessment. 2005. Ecosystems and human well-being: synthesis. Island, Washington, D.C., USA.

Mol, A. P. J., D. A. Sonnenfeld, and G. Spaargaren. 2009. The ecological modernisation reader: environmental reform in theory and practice. Routledge, London, UK.

Moquay, P. 2008. Défis de la territorialisation de l'intervention publique pour les services de l'état. Pages 199-218 in F. Aubert, V. Piveteau, and B. Schmitt, editors. Politiques agricoles et territoires. Quae, Versailles, France.

Moreno, J. L. 1960. The sociometry reader. Free Press, Glencoe, Illinois, USA.
Muller, P. 1990. Les politiques publiques entre secteurs et territoires. Politiques et Management Public 8(3):19-33. https:// doi.org/10.3406/pomap.1990.2951

Nettier, B., L. Dobremez, and P. Fleury. 2012. L'obligation de résultat pour les mesures agri-environnementales "prairies fleuries" et "gestion pastorale." Revue Sciences Eaux \& Territoires 5. [online] URL: http://www.set-revue.fr/lobligation-de-resultatpour-les-mesures-agri-environnementales-prairies-fleuries-et-gestion

Norgaard, R. B. 2010. Ecosystem services: from eye-opening metaphor to complexity blinder. Ecological Economics 69 (6):1219-1227. http://dx. doi.org/10.1016/j.ecolecon.2009.11.009

Ollivier, G., and S. Bellon. 2013. Dynamiques paradigmatiques des agricultures écologisées dans les communautés scientifiques internationales. Natures Sciences Sociétés 21(2):166-181. http:// dx.doi.org/10.1051/nss/2013093

Peet, R., P. Robbins, and M. Watts. 2010. Global political ecology. Routledge, London, UK. http://dx.doi.org/10.4324/9780203842249

Pérez-Vitoria, S. 2010. La riposte des paysans. Actes Sud, Arles, France.

Perraud, D. 1998. L'Europe verte. Les acteurs régionaux des politiques communautaires agricoles et rurales. INRA Editions, Versailles, France.

Plantureux, S., C. De Sainte Marie, C. Agreil, B. Amiaud, L. Dobremez, J. Fargier, P. Fleury, H. Fritz, J. L. Langlois, D. Madga, P. Mestelan, M. Meuret, T. Mougey, B. Nettier, C. Seres, and J. Y. Vansteelant. 2011. Analyse de la mise en œuvre des mesures agri-environnementales à obligation de résultat sur les surfaces herbagères. Fourrages 208:271-281.

Rosset, P. M., and M. A. Altieri. 1997. Agroecology versus input substitution: a fundamental contradiction of sustainable agriculture. Society \& Natural Resources 10(3):283-295. http://dx. doi.org/10.1080/08941929709381027

Sarandon, S., and C. Flores. 2012. L'agroécologie: un nouveau paradigme pour l'élaboration du développement rural durable. Pages 91-120 in F. Goulet, D. Magda, N. Girard, and V. Hernandez, editors. L'Agroécologie en Argentine et en France. Regards croisés. L'Harmattan, Paris, France.

Sevilla-Guzmán, E., and G. Woodgate. 2013. Agroecologia: fundamentos del pensamiento social agrario y teoria sociologica. Agroecologia 8(2):27-34.

Silvertown, J. 2015. Have ecosystem services been oversold? Trends in Ecology \& Evolution 30(11):641-648. http://dx.doi. org/10.1016/j.tree.2015.08.007

Tancoigne, E., M. Barbier, J.-P. Cointet, and G. Richard. 2014. The place of agricultural sciences in the literature on ecosystem services. Ecosystem Services 10:35-48. http://dx.doi.org/10.1016/ j.ecoser.2014.07.004

Tischler, W. 1965. Agrarökologie. Fischer, Jena, Germany.

Torre, A. 2009. Retour sur la notion de Proximité Géographique. Géographie, Économie, Société 11(1):63-73. http://dx.doi. org/10.3166/ges.11.63-73

Valette, E., O. Aznar, M. Hrabanski, C. Maury, A. Caron, and M. Decamps. 2012. Émergence de la notion de service 
environnemental dans les politiques agricoles en France: l'ébauche d'un changement de paradigme? VertigO 12(3). http:// dx.doi.org/10.4000/vertigo.12925

Wezel, A., S. Bellon, T. Doré, C. Francis, D. Vallod, and C. David. 2009. Agroecology as a science, a movement and a practice. A review. Agronomy for Sustainable Development 29(4):503-515.

Wezel, A., and V. Soldat. 2009. A quantitative and qualitative historical analysis of the scientific discipline of agroecology. International Journal of Agricultural Sustainability 7(1):3-18. http://dx.doi.org/10.3763/ijas.2009.0400 